\title{
Red/near-infrared irradiation therapy for treatment of central nervous system injuries and disorders
}

Melinda Fitzgerald a, b, Stuart Hodgetts a, c, Corinna Van Den Heuvel d, Riccardo Natoli e,

Nathan S. Hart ${ }^{\mathrm{b}}$, Krisztina Valter ${ }^{\mathrm{e}}$, Alan R. Harvey ${ }^{\mathrm{a}, \mathrm{c}}$, Robert Vink ${ }^{\mathrm{d}}$, Jan Provis ${ }^{\mathrm{e}}$, Sarah A.

Dunlop $^{\text {a, b }}$

Experimental and Regenerative Sciences ${ }^{a}$, School of Animal Biology, The University of Western Australia ${ }^{b}$, School of Anatomy, Physiology \& Human Biology, The University of

Western Australia ${ }^{c}$, School of Medical Sciences, The University of Adelaide ${ }^{d}$, ANU Medical School and John Curtin School of Medical Research, The Australian National University ${ }^{e}$

\section{Corresponding Author}

Asst Professor Melinda Fitzgerald: 61864882353 lindy.fitzgerald@uwa.edu.au

Stuart Hodgetts: Assoc Professor, The University of Western Australia

Corinna Van Den Heuvel: Assoc Professor, University of Adelaide

Riccardo Natoli: Senior Scientist, Australian National University

Nathan Hart: Assoc Professor, The University of Western Australia

Krisztina Valter: Senior Lecturer, Australian National University

Alan Harvey: Winthrop Professor, The University of Western Australia

Bob Vink: Chair of Neurosurgical Research and Head of the School of Medical Sciences at the University of Adelaide.

Jan Provis: Associate Dean, Professor of Anatomy, ANU Medical School

Sarah Dunlop: Winthrop Research Professor, The University of Western Australia 


\section{Abstract}

Irradiation in the red/near-infrared spectrum (R/NIR, $630 \mathrm{~nm}-1000 \mathrm{~nm}$ ) has been used to treat a wide range of clinical conditions including disorders of the central nervous system, with several clinical trials currently underway for stroke and macular degeneration. However, R/NIR irradiation therapy (R/NIR-IT) has not been widely adopted in clinical practice for CNS injury or disease for a number of reasons, as follows. The mechanism/s of action and implications of penetration ishave not been thoroughly addressed. still not clear. Furthermore, £ The large range of treatment intensities, wavelengths and devices that have been assessed make comparisons difficult and a consensus paradigm for treatment has not yet emerged. Furthermore, the lack of consistent positive outcomes in randomised controlled trials, perhaps due to sub-optimal treatment regimens, has contributed to scepticism. This review provides a balanced précis of outcomes described in synthesis of the literature regarding treatment modalities and efficacy of R/NIR-IT for injury and disease in the CNS. We have addressed the important issues of specification of treatment parameters, penetration of R/NIR irradiation to CNS tissues and mechanism, providing the necessary detail to demonstrate the potential of R/NIR-IT for treatment of retinal degeneration, damage to white matter tracts of the CNS, stroke and Parkinson's disease. We conclude with an assessment of the clinical application of R/NIR-IT for treatment of CNS injuries and disease.

Keywords: irradiation therapy, trauma - nervous system, retinal degeneration, Parkinson disease, 


\section{Table of Contents}

1.1 Introduction

1.2 Parameters of R/NIR-IT

1.3 Penetration of irradiation in the human brain

1.3.1 Extent of penetration (transmission)

1.3.2 Factors affecting penetration

1.3.3 Extremely low irradiation levels can affect cells

1.4 Potential mechanisms of efficacy of R/NIR-IT

1.5 R/NIR-IT for treatment of retinal degeneration

1.6 R/NIR-IT for treatment of damage to the optic nerve and visual cortex

1.7 R/NIR-IT for treatment of traumatic brain injury (TBI)

1.8 R/NIR-IT for treatment of spinal cord injury (SCI)

1.9 R/NIR - IT for treatment of stroke

1.9.1 Pre-clinical rabbit studies

1.9.2 Pre-clinical rodent studies

1.9.3 Acute ischaemic stroke clinical trial

1.10 R/NIR-IT for treatment of Parkinson's disease

1.11 Clinical application of R/NIR-IT 


\subsection{Introduction}

Irradiation in the red/near-infrared spectrum (R/NIR, $630 \mathrm{~nm}-1000 \mathrm{~nm})$ was developed as a therapeutic strategy for treatment of a range of injuries and diseases, following observations of beneficial effects on astronauts in space (Whelan et al., 2001). Therapeutic use of irradiation at these wavelengths is characterized by relatively low energy densities and is referred to as R/NIR-IT. It is distinct from high-energy ablative or thermocoagulatory laser treatments, or light dependent imaging techniques. Improvements following R/NIR-IT have been observed in a wide array of clinical conditions including wound healing (Whelan et al., 2003, Whelan et al., 2001, Yu et al., 1997), oral mucositis (Eells et al., 2004), cardial infarct size (Oron et al., 2001) and renal and hepatic complications during diabetes (Lim et al., 2009, Lim et al., 2010), although clinical efficacy is not always clear cut. Specific to the nervous system, beneficial effects have been reported following retinal degeneration (Albarracin and Valter, 2012b, Natoli et al., 2010), central nervous system (CNS) injury (Byrnes et al., 2005, Fitzgerald et al., 2010), stroke (Lapchak et al., 2007), peripheral nerve damage (Ishiguro et al., 2010, Rochkind et al., 2009) and for restless leg syndrome (Mitchell et al., 2011). However, R/NIR-IT has not been widely adopted in clinical practice for a number of reasons. Firstly as the mechanism/s of action are is/are still not clear and the impact of limited penetration of irradiation is unknown. Furthermeresecondly, the large range of treatment intensities, wavelengths and devices that have been employed make inter-trial comparisons difficult and a consensus paradigm for treatment of CNS injury or disease has not yet emerged from preclinical studies yet alone clinical ones. Finally, the lack of a definitive positive effect to date in randomised controlled trials, perhaps due to sub-optimal treatment regimens, has contributed to scepticism. 
Here we provide a synthesis of the literature regarding treatment modalities and efficacy of R/NIR-IT for injury and disease in the CNS. We begin by defining the principles of R/NIRIT, and emphasise the importance of specifying parameters of wavelength, intensity, duration of treatment and the nature of the irradiation administered, when reperting findingsto enable comparison across different studies. R/NIR-IT cannot be effective without adequate penetration to the target tissue and to this end we have reviewed information describing penetration of R/NIR irradiation to CNS tissue and included additional calculations to aid interpretation. We briefly address mechanistic elements common to R/NIR-IT therapy across a range of disease and injury conditions and then comprehensively review the literature referring to retinal degeneration, damage to the optic nerve (ON) and visual cortex, spinal cord injury (SCI), traumatic brain injury (TBI), stroke and Parkinson's disease. Further, we provide a detailed tabulated comparison of the studies described, with information detailing: models used, irradiation source, intensity, wavelengths, duration of treatments and outcomes. We conclude by providing an assessment of the potential clinical application of R/NIR-IT for treatment of CNS injuries and disorders.

\subsection{Parameters of R/NIR-IT}

Despite positive results from preclinical research studies and successful clinical trials, as well as the obvious appeal of a relatively cheap and easily administered therapy, R/NIR-IT remains controversial and little used in mainstream medicine (Huang et al., 2011). This is in large part due to the lack of a standardized technical approach: search of the literature reveals a bewildering array of irradiation sources (laser or light-emitting diode), mode of delivery (pulsed or continuous), stimulation wavelength $(630,670,780,810,830,880,904 \mathrm{~nm})$, total dose (i.e. joules of irradiation per unit area), rate of delivery of the irradiation energy (watts 
per unit area [note: watts $=$ joules $\mathrm{x}$ time], also referred to as fluence), duration (length of exposure), timing (pre- or post insult) and frequency of treatment (Quirk and Whelan, 2011). This is confounded by the fact that dosages are usually specified in energy rather than quantal units; because photon energy varies with wavelength, an equal energy dose at different wavelengths will comprise different numbers of photons, and it is the number of photons interacting with a target photoacceptor that define the actual dose. While a range of treatment parameters have been trialled, we find few studies where variations in wavelength, total dose and dose rate have been tested in the same model. In short, while the empirical basis of R/NIR-IT for CNS injury and neurodegenerative disease is sound, its clinical application is hampered by uncertainty regarding treatment parameters. As an example of this variability, a comparison of parameters used in pre-clinical studies of R/NIR-IT for treatment of CNS injury or Parkinson's disease is provided in Table 1.

\subsection{Penetration of irradiation in the human brain}

The extent to which R/NIR irradiation can penetrate the brain is a key determinant of potential efficacy. Here we describe factors affecting penetration and give some biophysical examples to demonstrate that extremely low irradiation levels are sufficient to affect cells.

\subsubsection{Extent of penetration (transmission)}

When irradiation strikes biological tissue it is absorbed, scattered or transmitted. Optimal penetration within biological tissues occurs within a "therapeutic" or "optical window" with a wavelength range of $600-1000 \mathrm{~nm}$ (Parrish, 1981). The effective penetration depth of a given wavelength of irradiation is dependent upon the optical properties of the tissue, i.e. absorption and scattering (Cheong et al., 1990). Irradiation in the range of $600-1000 \mathrm{~nm}$ penetrates tissue because scattering by tissue inhomogeneities is dominant (Profio, 1989). 
Scattering increases the distance travelled by photons thus diffusing the propagating irradiation. Absorption occurs predominantly by chromophores such as melanin and haemoglobin at short wavelengths and water and cytochrome c oxidase, a photoacceptor within the mitochondrial electron transport chain, at longer wavelengths (Karu, 1989, Sutherland, 2002).

Detailed characterisation of irradiation distribution in tissues is highly complex and ultimately requires the extrapolation of measurements that, for technical reasons that are discussed further below, must be made on samples that are considerably thinner than the tissue or organ of interest (Lenz, 1999). Issues such as tissue fixation, the limitations in availability and access to appropriate regions within living tissue as well as the limitation of the sensitivity of available equipment used to measure irradiation intensity, must all be considered. However, the theory of irradiation transmission through highly scattering media is well established and theoretical approximations commonly used to derive optical penetration depth (delta, $\delta$ ) closely follow empirical measurements (Stolik et al., 2000). $\delta$ is the tissue thickness that causes irradiation to be attenuated to $37 \%$ its initial value (Muller and Wilson, 1986), i.e. not the maximum distance that irradiation will penetrate a tissue sample.

By way of example, we have used a diffusion model (Svaasand and Ellingsen, 1983) to calculate irradiation penetration to the centre of the human brain. We assumed brain dimensions of W140 $\mathrm{mm} \times \mathrm{L} 167 \mathrm{~mm} \times \mathrm{H} 93 \mathrm{~mm}$, and a surface irradiance of $60 \mathrm{~mW} / \mathrm{cm}^{2}$ (e.g. the FDA-approved Vet 75 device at $670 \mathrm{~nm}$, Quantum Devices Inc., Barneveld, WI) and that the head would be illuminated from the top, with the irradiation source positioned above the shaved scalp. We also assumed that the optical penetration depth of the skull is similar to 
that of the overlying skin and the brain (Firbank et al., 1993), suggesting that all these tissues (and any other sub-cranial tissues and fluids) pass irradiation at any particular wavelength in a similar fashion, thereby simplifying calculations.

Calculated fluence rates just inside the cranium (assumed to be $\sim 7 \mathrm{~mm}$ thick with a $3 \mathrm{~mm}$ thick skin covering to give a total thickness of $10 \mathrm{~mm}$ ) were calculated to be $2.5 \mathrm{~mW} / \mathrm{cm}^{2}$ for $670 \mathrm{~nm}$ irradiation $\left(\delta=2.4 \mathrm{~mm}^{-1}\right)$ and $13 \mathrm{~mW} / \mathrm{cm}^{2}$ for $1064 \mathrm{~nm}\left(\delta=4.0 \mathrm{~mm}^{-1}\right)$. Note that these two wavelengths are chosen as they are commonly used in R/NIR-IT; $670 \mathrm{~nm}$ irradiation is thought to change the oxidation reduction state of cytochrome c oxidase (see below) and $1064 \mathrm{~nm}$ irradiation is transmitted better through biological tissues (Karu, 1989, Sutherland,

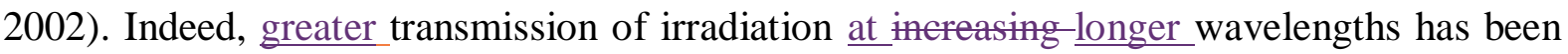
shown previously for a total human scalp and skull thicknesses of up to $13 \mathrm{~mm}$ (Wan et al., 1981). By contrast, and due to the exponential relationship between irradiation penetration and tissue thickness, fluence rates in the centre of the brain $(10 \mathrm{~mm}$ skull and skin $+46 \mathrm{~mm}$ brain $=56 \mathrm{~mm}$ ) were calculated to be very much lower at $1.2 \times 10^{-11} \mathrm{~W} / \mathrm{cm}^{2}$ for $670 \mathrm{~nm}$ irradiation and $1.4 \times 10^{-7} \mathrm{~W} / \mathrm{cm}^{2}$ at $1060 \mathrm{~nm}$. The considerably greater $\left(10^{4}\right)$ value for the penetration of longer wavelength irradiation calculated to reach the centre of the brain is in agreement with other studies comparing tissue penetration for a variety of wavelengths (Eichler et al., 1977, Lenz, 1999, Neupane et al., 2010).

To our knowledge, only two studies have directly measured the penetration of R/NIR irradiation in intact animals. Spectrophotometric and power transmission analyses in rat revealed that $6 \%(9 \mathrm{~mW})$ of transcutaneous $810 \mathrm{~nm}$ laser irradiation (power output $150 \mathrm{~mW}$ ) was transmitted from the dorsal surface of the skin to the ventral side of the spinal cord (Byrnes et al., 2005). Similarly, a study in rat showed that when irradiation was directed at 
the dorsal surface of the head (total R/NIR irradiance $\left.252 \mathrm{~W} / \mathrm{m}^{2} 550-750 \mathrm{~nm}\right), 0.7 \%(1.75$ $\left.\mathrm{W} / \mathrm{m}^{2}\right)$ reached the ventral surface of the optic nerve, and $0.1 \%\left(0.3 \mathrm{~W} / \mathrm{m}^{2}\right)$ the ventral surface of the braincase (Fitzgerald et al., 2010).

\subsubsection{Factors affecting penetration}

A number of factors affect R/NIR irradiation penetration of tissue. Haemoglobin and water are major chromophores, i.e. they absorb irradiation (Sterenborg, 1989), thus the extent of R/NIR irradiation penetration will presumably vary according to vascularisation and fluid balance. Although the absorption coefficient of water is low in the visible region, it is significant for R/NIR irradiation and the large volume fraction of water in biological tissue, together with haemoglobin, contributes significantly to absorption (Ankri et al., 2010). Indeed, in ex vivo human kidney and liver tissue, $\delta$ is greater for slices containing blood compared to those in which the blood had been removed (Eichler et al., 1977). Furthermore, $\delta$ values obtained from freshly resected human brain tissue were greater in malignant brain tumours that were more vascularised, compared to normal brain tissue (Muller and Wilson, 1986). Both vascularisation and water balance are profoundly influenced in neurodegenerative disease such as Alzheimer's and Parkinson's as well as stroke. For example, $\beta$-amyloid promotes angiogenesis and blood brain barrier permeability in $\operatorname{Tg} 2576$ AD mice (Biron et al., 2011) and in humans with cerebral amyloid angiopathy (Hartz et al., 2012) while integrin $\alpha v \beta 3$, a marker for angiogenesis, is increased in human PD brains (Desai Bradaric et al., 2012). Aquaporin expression, indicative of changed water transport, is enhanced in AD brains (Moftakhar et al., 2010) and blood brain barrier permeability is increased following ischaemic stroke (Hom et al., 2011, Topakian et al., 2010). Not unexpectedly, vascular damage is also extensive following TBI both acutely (Iwamura et al., 2012) and with evidence for long term remodelling (Rodriguez-Baeza et al., 2003). Reactive 
gliosis is a further contributor to changes in cellular architecture that may modulate penetration of R/NIR-IT (Sykova and Vargova, 2008). However, in these pathological conditions, it is unknown whether the increased blood supply and changed water balance would act as a more prominent substrate for the absorbance of R/NIR irradiation during therapy.

Oxygenation also influences penetration of irradiation. Compared to room air $\left(21 \% \mathrm{O}_{2}\right.$; $\left.0.039 \% \mathrm{CO}_{2}\right)$, carbogen breathing $\left(95 \% \mathrm{O}_{2}: 5 \% \mathrm{CO}_{2}\right)$ in mice increased the penetration of R/NIR irradiation and improved the outcome of photodynamic therapy for tumour ablation (Mitra and Foster, 2004). Conversely, in situations where hypoxia occurs such as after traumatic and hypoxia-ischaemia induced brain injury (Howards, 2012, Oddo et al., 2011), any therapeutic use of R/NIR irradiation may require higher intensity irradiation to offset reduced tissue penetration. Myelination is also thought to influence penetration of irradiation with greater $\delta$ values in grey compared to white matter (Lenz, 1999). A study in bovine brain showed that irradiation penetration was greatest when irradiation was oriented parallel to white matter tracts (Hebeda et al., 1994), a finding that explains the increased incidence of lesions within the corpus callosum after photodynamic therapy in normal mouse brain (Sandeman, 1986).

\subsubsection{Extremely low irradiation levels can affect cells}

The foregoing calculations suggest that fluence/fluence rates at limited depths into the skull and brain are quite significant. A 20 minute exposure to a $60 \mathrm{~mW} / \mathrm{cm}^{2} 670 \mathrm{~nm}$ LED array (e.g. Vet 75) positioned above the head would give a total fluence (irradiation dose) of $\sim 3$ $\mathrm{J} / \mathrm{cm}^{2}$ at a fluence (dose) rate of $2.5 \mathrm{~mW} / \mathrm{cm}^{2}$ to the surface of the brain just under the cranium. This is within known effective dose / rate ranges (cf. (Huang et al., 2011)). Whether 
or not the extremely low level of irradiation reaching the centre of the brain is 'effective' for irradiation therapy of CNS injury or disease remains to be determined.

Nevertheless, very low levels of irradiation can trigger significant biophysical phenomena. For example, at the threshold of useful vision - such as when we are able to detect the edges of large objects at night under a moonless, overcast sky - the ambient light intensity is such that (on average) each rod photoreceptor in the retina only absorbs a single photon of light or irradiation every 84 minutes. Even at dawn when there is enough light to see clearly, and objects appear coloured because cones are also active, rods are only capturing (on average) one photon every 5 seconds (Rodieck, 1998). However, because the retina contains around 90 million rods (Curcio et al., 1990), we are able to use this limited information to form an image and not just detect light. To put this into context, the intensity of the dimmest extended light source that can be seen by a human corresponds to a fluence rate of $1.5 \times 10^{-14} \mathrm{~W} / \mathrm{cm}^{2}$, i.e. well below that reaching the centre of the brain in our modelled scenario above. Although the exact mechanism of R/NIR-IT remains to be elucidated, it is clear that the low levels of irradiation encountered are more than capable of triggering cellular signalling and probably sufficient to drive metabolic events.

\subsection{Potential mechanisms of efficacy of R/NIR-IT}

Several recent reviews have summarized existing knowledge regarding the potential mechanisms by which R/NIR-IT exerts its effects (Chung et al., 2012, Hashmi et al., 2010) and we therefore address this subject relatively briefly. Cytochrome $c$ oxidase is proposed to act as a photoacceptor for irradiation at these wavelengths, with absorption spectra matching efficacious wavelengths and irradiation leading to changes in the oxidation reduction state of 
the enzyme (Karu, 1999, Karu and Kolyakov, 2005, Karu et al., 2005, Karu et al., 2008). Increases in cytochrome $c$ oxidase activity with R/NIR-IT are associated with increases in ATP content in treated tissues, indicating increased flux through the electron transport chain (Lapchak and De Taboada, 2010, Wong-Riley et al., 2005). While it has been proposed that these changes are associated with increased reactive oxygen species and resultant downstream signalling (Chung et al., 2012, Hashmi et al., 2010), it is important to note that studies linking various facets of oxidative metabolism to ROS/RNS production have been contradictory, largely conducted in vitro, and highly dependent on the timing of experimental observations and the conditions employed (Peng and Jou, 2010, Tretter et al., 2007). Indeed it is possible that increased flux of electrons through the electron transport chain may maintain mitochondrial membrane potential, reduce passage through the reverse electron transport chain, alter cAMP release and increase ATP synthesis, all of which may result in reduced leakage of free radical intermediates (Camello-Almaraz et al., 2006, Kowaltowski et al., 2009, Rojas et al., 2008). While direct deductions concerning the sequence of effects in mitochondria with R/RIR-IT are problematic with the existing information available to us, R/NIR-IT has been shown to improve indices of mitochondrial function following damage to the CNS in a range of model systems, many of which have been associated with improvements in function (Eells et al., 2004, Rojas et al., 2008). Further descriptions of reported effects of R/NIR-IT on cytochrome $c$ oxidase and mitochondrial function in specific CNS injury and disease states are provided in the sections below.

While a significant proportion of the available data on mechanism of R/NIR-IT point towards cytochrome $c$ oxidase as a primary photoacceptor, this does not preclude other potential modes of action. The chromophores melanin and haemoglobin may also play a role (Karu, 1989, Peoples et al., 2012a, Sutherland, 2002). Nitric oxide released from cytochrome $c$ 
oxidase may lead to downstream vasodilatation (Ball et al., 2011, Mason et al., 2006) and signal transduction, potentially also contributing to functional improvements. R/NIR-IT has been shown to modulate gene expression (Natoli et al., 2010), reduce apoptosis (Liang et al., 2008, Wong-Riley et al., 2005), alter cytokine release and modulate immune responses (Moreira et al., 2009)(Albarracin and Valter, 2012a)(Kokkinopoulos et al., 2012) (personal observation), and these outcomes may be up/down-stream or independent of modulation of cytochrome $c$ oxidase activity.

\subsection{R/NIR-IT for treatment of retinal degeneration}

The studies discussed here employ R/NIR LED devices to deliver a therapeutic dose to the retina in an experimental setting, or to monitor effects on the aging retina. The high metabolic activity of photoreceptors renders the retina highly susceptible to oxidative damage (Winkler, 1981) (Yu et al., 1999). Oxidative damage to photoreceptors has been implicated in many forms of retinal degeneration including Age-Related Macular Degeneration (AMD) (Multipleauthors, 2001), retinitis pigmentosa (Shen et al., 2005), retinopathy of prematurity (Tsukahara et al., 2004) and in the later stages of all photoreceptor degenerations regardless of the initiating event (Stone et al., 1999). Arguably, amelioration of oxidative damage is the key to long-term survivability of the retina. Several laboratories have now used R/NIR irradiation to attenuate experimentally induced retinal degeneration, including models of AMD (Albarracin et al., 2011, Albarracin and Valter, 2012a, Albarracin and Valter, 2012b, Natoli et al., 2010, Qu et al., 2010), Parkinson's-related retinopathy (Peoples et al., 2012a) and methanol (Eells et al., 2003) and rotenone (Rojas et al., 2008) toxicity, with beneficial effects in normal aging (Kokkinopoulos et al., 2012). None of these studies report any adverse effects of $670 \mathrm{~nm}$ irradiation on the retina. 
Methanol is a potent mitochondrial toxin, which inhibits cytochrome oxidase activity (Seme et al., 1999). Eells et al., (2003) reported the first direct link between mode of action of R/NIR irradiation in retinoprotection, using a methanol toxicity model. They found that mitochondrial damage in photoreceptors caused by methonal toxicity was reduced by exposure to $670 \mathrm{~nm}$ irradiation. Mitochondria retained their normal structure in animals intoxicated with methanol and treated with $670 \mathrm{~nm}$ irradiation. Rod and cone response amplitudes (electroretinogram) were reduced up to $75 \%$ by methanol toxicity; however, when combined with $4 \mathrm{~J} / \mathrm{cm} 2$ treatments of $670 \mathrm{~nm}$ irradiation at 5,25 and $50 \mathrm{hrs}$ of methanol intoxication, response amplitudes were reduced by only $\sim 33 \%$. The authors concluded that because formic acid (derived from breakdown of methanol) acts directly to inhibit cytochrome $c$ oxidase, a key enzyme in mitochondrial metabolism, 670nm irradiation appeared to be directly modulating enzyme activity to reduce this toxic effect and promote mitochondrial function. In an in vivo study in the rat retina, $633 \mathrm{~nm}$ irradiation was protective against Rotenone, a potent inhibitor of mitochondrial function, providing a further direct link between these organelles and R/NIR irradiation (Rojas et al., 2008). This link has also been noted in experiments using the mitochondrial dye JC-9, in which there is a shift in mitochondrial membrane potential in retinal pigment epithelial cells in direct response to 670nm irradiation (Kokkinopoulos et al., 2012).

Oxidative damage generated by excessive photo-oxidation of the rod outer segments is thought to be the initiating event in light-induced retinal damage (LD) (Demontis et al., 2002). However, it has also been shown in LD that retinal degeneration continues long after removal of the damaging stimulus (white light) (Rutar et al., 2010). This progressive 
degeneration has been used to model the factors contributing to expansion of the degenerative area, as occurs in AMD, and appears to be largely mediated by inflammation (Hollyfield et al., 2008). Microarray analysis (Natoli et al., 2010) shows that expression of genes in pathways involved in inflammation, apoptosis and metabolism are down-regulated in LD retinas treated with $670 \mathrm{~nm}$ irradiation. One of the most highly modulated genes identified in that study is $\mathrm{Ccl} 2$ - a potent chemokine involved in recruitment of macrophages to sites of tissue injury. $\mathrm{Ccl} 2$ has become a gene of interest from investigations in models of AMD and this chemokine family is now implicated in its pathogenesis (Rutar et al., 2011).

Several studies find that $670 \mathrm{~nm}$ irradiation is protective against retinal degeneration in LD, citing histological, functional and molecular evidence (Albarracin et al., 2011, Albarracin and Valter, 2012a, Natoli et al., 2010, Qu et al., 2010). Treatment with 670nm irradiation before, during or after exposure to damaging white light attenuates retinal degeneration (Albarracin et al., 2011, Qu et al., 2010), protects photoreceptor function and reduces expression of stress markers in the retina, as well as microglial and macrophage invasion (Albarracin and Valter, 2012a). While treatment prior to exposure to bright light is most effective, animals treated with $670 \mathrm{~nm}$ after light damage recover photoreceptor function by one month post-exposure (Albarracin et al., 2011). LD induces upregulation of a number of markers of oxidative stress and these are downregulated by 670nm irradiation (Natoli et al., 2010). Two independent studies report downregulation of the pro - inflammatory cytokine TNF-alpha following treatment with 670nm irradiation. In the first, quantitative PCR was used to show a reduction in TNF alpha levels in the LD retina pre-treated with 670nm irradiation (Albarracin and Valter, 2012a). In the second, it was shown that treatment of aged mice with $670 \mathrm{~nm}$ irradiation reduces TNF-alpha immunoreactivity, as well as recruitment of IBA1 positive macrophages to outer retina, and $\mathrm{C} 3 \mathrm{~b}$ and $\mathrm{C} 3 \mathrm{~d}$ immunoreactivity in Bruch's membrane 
(Kokkinopoulos et al., 2012), all indicating downregulation of inflammatory responses. In addition, components of the 'classical' pathway of complement activation, as well as C3 are downregulated by pretreatment with 670nm irradiation in the LD model (unpublished observation).

Collectively these studies provide strong evidence that $670 \mathrm{~nm}$ irradiation gives significant protection to the retina, and some studies indicate that cytochrome $c$ oxidase is the most likely photo-acceptor. The observed effects can be explained by a theoretical model of 670 nm IT promoting effective mitochondrial function, resulting in a reduction of free radical production and oxidative damage. The downstream effects appear to be a downregulation of inflammatory processes. The LD model specifically, and the retina in general, are ideal models to explore the mechanisms, potential and limitations of R/NIR irradiation treatments, due to the relative ease of inducing damage, the known interactions between oxidative stress and inflammatory pathways, combined with accessibility for treatment.

\subsection{R/NIR-IT for treatment of damage to the optic nerve and visual cortex}

Evidence supporting the role of cytochrome $c$ oxidase as a key photo-acceptor for irradiation in the R/NIR spectrum has also been generated in studies of neurons from the visual cortex. In vitro experiments assessing the effects of inhibitors on neurons from the postnatal rat visual cortex demonstrate that $\mathrm{KCN}$ inactivation of cytochrome $c$ oxidase (by $100 \mu \mathrm{M} \mathrm{KCN}$ or less) is reversed by treatment with $670 \mathrm{~nm}$ irradiation delivered by LED array once or twice daily for 100 seconds (energy density $=4 \mathrm{~J} / \mathrm{cm}^{2}$, power density $=50 \mathrm{~mW} / \mathrm{cm}^{2}$ ) (WongRiley et al., 2001, Wong-Riley et al., 2005). Effects with twice daily treatments are more 
pronounced for neurons lightly reactive for cytochrome c oxidase activity (Wong-Riley et al., 2005). Longer pretreatments with $670 \mathrm{~nm}$ irradiation (10 minutes prior to $\mathrm{KCN}$ exposure, equivalent to $30 \mathrm{~J} / \mathrm{cm}^{2}$ ) significantly reduce nuclear condensation (Wong-Riley et al., 2005), attributed to reduced apoptosis and associated with reduced oxidative stress (Liang et al., 2006). The effects of a range of wavelengths of irradiation delivered via LED array in the R/NIR spectrum on cytochrome $c$ oxidase activity following blockade of voltage dependent sodium channels with tetrodotoxin, have also been compared in visual cortical neurons. 670 $\mathrm{nm}$ and $830 \mathrm{~nm}$ irradiation (energy density $=4 \mathrm{~J} / \mathrm{cm}^{2}$, power density $=50 \mathrm{~mW} / \mathrm{cm}^{2}$ ) restores cytochrome $c$ oxidase activity and ATP content, whereas $728 \mathrm{~nm}, 770 \mathrm{~nm}$ and $880 \mathrm{~nm}$ irradiation are less effective (Wong-Riley et al., 2005). Effective wavelengths correlate positively with the known absorption spectra of oxidised cytochrome $c$ oxidase (Carter and Palmer, 1982, Karu, 1999, Karu et al., 2008, Wong-Riley et al., 2005).

Cytochrome $c$ oxidase activity in RGC somata has been linked to survival of these cells following complete $\mathrm{ON}$ transection (von Bussmann et al., 1993). While cytochrome $c$ oxidase activity is higher in unmyelinated than myelinated regions of the human $\mathrm{ON}$ (Balaratnasingam et al., 2009), we have recently demonstrated in vivo that cytochrome c oxidase activity is increased in $\mathrm{ON}$ following partial $\mathrm{ON}$ transection and $670 \mathrm{~nm}$ irradiation treatment (LED, 30 minutes / day, $25 \mathrm{~mW} / \mathrm{cm}^{2}$ ), and that activity colocalised with oligodendrocytes, at least in the short term (unpublished observation). Increased cytochrome $c$ oxidase activity in $\mathrm{ON}$ is associated with reduced oxidative stress, both in nerve homogenates and more specifically in astrocytes (Fitzgerald et al., 2010) and oligodendrocytes (unpublished observation). $670 \mathrm{~nm}$ irradiation (LED) treatment also decreases proliferation of oligodendrocyte progenitor cells (Fitzgerald et al., 2010) and reduces paranode elongation in injured $\mathrm{ON}$ vulnerable to secondary degeneration, associated 
with later preservation of RGC numbers and restoration of visual function (Fitzgerald et al., 2010) (unpublished observation). Similarly, daily treatments of rat ON crush injuries with $630 \mathrm{~nm}$ irradiation (delivered by He-Ne laser, $10.5 \mathrm{~mW}$ ) for 2 weeks significantly increases compound action potentials in ON ex vivo and postpones degeneration (Assia et al., 1989). For positive effects, treatment needs to be rapidly initiated (less than 5 hours after injury), maintained, and used on moderately rather than severely injured nerves (Assia et al., 1989).

\subsection{R/NIR-IT for treatment of traumatic brain injury (TBI)}

Neuropathological consequences of TBI include disruption in axonal transport leading to axonal swelling followed by secondary disconnection, extensive demyelination and Wallerian

degeneration (Johnson et al., 2012, Tang-Schomer et al., 2012) (Brambilla et al., 2006). Alterations to mitochondria (including membrane permeability) influence axonal integrity as well as ionic imbalance, oxidative stress and lipid peroxidation (associated with both mitochondrial dysfunction and cytoskeletal degradation) which play a central role post-injury in both axonal degeneration and dysfunction of viable and intact axons (Buki et al., 1999, Johnson et al., 2012, Maxwell et al., 2003). Of the ten TBI studies presented here describing R/NIR-IT in mice (Ando et al., 2011, Khuman et al., 2012, Oron et al., 2007, Oron et al., 2012, Wu et al., 2012), rats (Moreira et al., 2009, Quirk et al., 2012) and humans (Naeser et al., 2011, Nawashiro et al., 2012), eight reported effects in acute (short term) or sub-acute, and only one in chronic (long term) (Naeser et al., 2011) contusive TBI. Of these ten studies, nine used lasers to deliver the R/NIR-IT. A further study using laser delivered R/NIR-IT (McCarthy et al., 2010) provides evidence that treatment with 808nm wavelength in the uninjured rat brain is safe at single and multiple doses (Table 1), with no treatment-related lesions, neoplasia or other toxicological abnormalities for up to 1 year after injury (McCarthy 
et al., 2010). Most rodent model studies report statistically significant improvements in outcomes including: Neurological Severity Scores (NSS), evidence of increased axonal numbers and distance of re-growth, reduced lesion size, modulation of apoptotic and inflammatory responses, and pronounced anti-depressant effects.

Treatment of TBI generated by cortical impactor device in mice, with $808 \mathrm{~nm}$ Gs-As (gallium - arsenide) diode laser (10 and $20 \mathrm{~mW} / \mathrm{cm}^{2}, 1.2-2.4 \mathrm{~J} / \mathrm{cm}^{2}$ ) for 2 minutes (at 4 hours post trauma) results in no significant improvements in NSS up to 48 hours after treatment. However, from day 5 - 28, NSS are reduced by about $27 \%$ in irradiated mice which also have smaller lesion sizes compared to controls (1.4\% vs 12.1\%) (Oron et al., 2007). Continuous wave (CW) GaAIAs (gallium - aluminium - arsenide) $780 \mathrm{~nm}$ or InGaAIP $660 \mathrm{~nm}$ low level laser irradiation following a 40 second cryoinjury to the brain results in immunomodulation of TNF- $\alpha$, IL10, IL1 $\beta$ cytokine responses following R/NIR-IT (Moreira et al., 2009), although no functional recovery studies were performed in this study. Neuroprotective effects are also seen with $808 \mathrm{~nm}$ GaAIAs laser treatment at $50 \mathrm{~mW} / \mathrm{cm}^{2}(\mathrm{CW}$ at $10 \mathrm{~Hz}$ and Pulsed wave $(\mathrm{PW})$ at $100 \mathrm{~Hz}$ ) for 12 minutes at 4 hours, following contusive TBI in mice. These neuroprotective effects, which are more pronounced after $10 \mathrm{~Hz}$ PW frequency treatment than $100 \mathrm{~Hz} \mathrm{CW}$, include improved behavioural recovery (NSS), reduced brain lesion volume and a pronounced anti-depressant effect at up to 4 weeks post TBI (Ando et al., 2011). A 2 - 7 minute exposure to $800 \mathrm{~nm}$ GaAIAs laser treatment at a variety of doses $(250,500$ or 1000 $\mathrm{mW} / \mathrm{cm}^{2}$ ), at $60-80$ minutes or 4 hours after contusive TBI in mice results in no effects on post-injury motor function (days 1 - 7), brain edema (24 hours), nitrosative stress (24 hours), or lesion volume (14 days), however there are improved cognitive outcomes and inhibition of microglia activation (Khuman et al., 2012). 
Four weeks after a single 4 minute exposure at 4 hours post contusive TBI $\left(36 \mathrm{~J} / \mathrm{cm}^{2} \mathrm{CW}\right.$, $665 \mathrm{~nm}, 730 \mathrm{~nm}, 810 \mathrm{~nm}$ or $980 \mathrm{~nm}$ ) in mice, there is improved behavioural recovery (NSS) and reduced brain "deficits", but only in $665 \mathrm{~nm}$ and $810 \mathrm{~nm}$ treated animals (Wu et al., 2012). Treatment of rats with $670 \mathrm{~nm}$ irradiation (at $50 \mathrm{~mW} / \mathrm{cm}^{2}, 15 \mathrm{~J} / \mathrm{cm}^{2}$ ) for $2 \times 5 \mathrm{~min}$ per day for 72 hours or 10 days, post contusive TBI, results in functional (NSS) and morphological improvements, including decreased pro-apoptotic Bax expression and increased anti-apoptotic Bcl2 expression (Quirk et al., 2012). Finally Oron et al (2012) using an $808 \mathrm{~nm}$ GaAIAs laser to deliver $10 \mathrm{~mW} / \mathrm{cm}^{2}\left(1.2 \mathrm{~J} / \mathrm{cm}^{2}\right.$ ) treatment (either $\mathrm{CW}$ or PW, at 100 or $600 \mathrm{~Hz}$ ) for 2 minutes (at either 4, 6, or 8 hours post trauma) following contusive TBI in mice show improved neurobehavioural function (NSS) and an overall reduction in lesion size at 56 days (Oron et al., 2012). It has been proposed, based mainly on in vitro cortical neuron models (see above), that R/NIR-IT benefits recovery from TBI by inhibiting apoptosis whilst increasing mitochondrial activity, transcriptional activation, angiogenesis and neurogenesis (Chung et al., 2012)(Huang et al., 2012).

In humans, R/NIR-IT using $830-870 \mathrm{~nm}$ irradiation has been tested in a 40 year old male (2 x 30 min treatments per day for 73 days, applied $5 \mathrm{~mm}$ from skin at $11.4 \mathrm{~mW} / \mathrm{cm}^{2}, 20.5 \mathrm{~J} / \mathrm{cm}^{2}$ (Nawashiro et al., 2012) and in two females aged 52 and 59. In the latter case, R/NIR-IT using 633 / $870 \mathrm{~nm}$ was administered either (i) as treatments of 5 minutes duration and 10 seconds per area treated for 7 months, then 3 weeks per month at $25.8 \mathrm{~mW} / \mathrm{cm}^{2}(\mathrm{CW})$ or (ii) daily for 7 minutes duration per area for 1 month, increasing by 1 minute per area for each successive month at $22.2 \mathrm{~mW} / \mathrm{cm}^{2}(\mathrm{CW})$ ) for treatment durations ranging from 3 months to 7 years (Naeser et al., 2011). In both studies, improved neurological outcomes (including executive function and memory) are reported, as well as reduced post-traumatic stress disorder and improved cerebral blood flow in chronic TBI (Naeser et al., 2011, Nawashiro et 
al., 2012). Patients were able to eventually self-treat in the home, but benefits are reduced if the daily / weekly treatment frequency is not maintained.

\subsection{R/NIR-IT for treatment of spinal cord injury (SCI)}

Pathological changes following acute SCI are characterised by focal injury (Sekhon and Fehlings, 2001) followed by an expanding wave of secondary degeneration and cell death (Baptiste and Fehlings, 2006, Nashmi and Fehlings, 2001, Park et al., 2004), that is associated with oxidative damage (Keane et al., 2006, Liu et al., 1997, Profyris et al., 2004). Of the three SCI studies presented here, all describe R/NIR-IT using lasers in rats (Byrnes et al., 2005, Medalha et al., 2010, Wu et al., 2009). To date, no R/NIR irradiation treatments have been reported in humans with SCI. In all rat studies, treatment began either immediately (Medalha et al., 2010, Wu et al., 2009) or within 15 minutes (Byrnes et al., 2005) after SCI, which involved either; dorsal hemisection at T9 - 10 alone (Byrnes et al., 2005), dorsal hemisection at T9 or moderate contusion at T9 - 10 (10g dropped from $12.5 \mathrm{~mm}$, NYU impactor) (Wu et al., 2009), or complete transection (Medalha et al., 2010) (Table 1).

R/NIR-IT using $810 \mathrm{~nm}$ irradiation ( 2 week treatment at $1,589 \mathrm{~J} / \mathrm{cm}^{2} /$ day) results in increased axonal number and distance of regrowth, as well as immunomodulation and some aspects of functional recovery improvement (as measured by ladder footfall, run time and hindlimb paw placement - but no open field (Basso, Beattie and Bresnahan) assessment) (Byrnes et al., 2005). Similarly, $810 \mathrm{~nm}$ irradiation treatment (daily for 14 days at 2,997 seconds per day, $1,589 \mathrm{~J} / \mathrm{cm}^{2} /$ day) results in increased axon length and number in both dorsal hemisection and moderate contusion SCI models (Wu et al., 2009). In the contusion model, improved open field (BBB) locomotion scores are reported with R/NIR-treated rats reaching BBB scores of 12 - 13 at 3 weeks after injury (ie. frequent to consistent weight supporting plantar steps with 
frequent coordination between fore- and hind-limbs) compared to non-treated rats reaching BBB scores of 9 - 10 (ie. occasional weight-supported plantar steps but with no coordination) (Wu et al., 2009). More recently, 830 nm-treated rats show a "trend" toward improved hindlimb diaphysis, but no biomechanical or densitometric improvements following complete spinal cord transection (Medalha et al., 2010). No behavioural (locomotory) improvements as measured by BBB scoring are observed in any treatment group. It is of note however, that the $830 \mathrm{~nm}$ treatment was not actually applied directly to the spinal cord in this study, rather at two points on the hindlimb (Medalha et al., 2010).

\subsection{R/NIR - IT for treatment of stroke}

Although at least 1000 agents have been shown to be efficacious in preclinical ischaemic stroke evaluation, to date only intravenous tissue plasminogen activator (tPA) has been approved for clinical use in treating acute ischaemic stroke (Segura et al., 2008). However, the majority of stroke patients either do not meet the strict criteria for treatment with tPA or fail to receive adequate reperfusion. Therefore, additional new therapies are needed. Recently, non-invasive laser therapy has been applied to acute ischaemic stroke patients with positive results; specifically, R/NIR irradiation is applied to the scalp within 24 hours of stroke symptoms onset. The principle objective of this section is to evaluate the literature regarding R/NIR-IT delivered by laser, in experimental stroke models and recent clinical trials, demonstrating that the most advanced application for R/NIR-IT to date is in ischaemic stroke with promising pre-clinical and clinical results. This subject has recently been comprehensively reviewed by Lapchak (2012); as such, details are provided for purposes of comparison with other CNS injury and disease states. 


\subsubsection{Pre-clinical rabbit studies}

Positive findings of the efficacy of R/NIR-IT in reducing lesion volume in myocardial infarction (Ad and Oron, 2001) prompted an investigation into whether a similar procedure would reduce stroke-related behavioural deficits due to the similarities between myocardial and cerebral ischaemia. A small clot embolic stroke model (RSCEM) was used in rabbits treated with transcranial R/NIR-IT, employing a continuous wave $(\mathrm{CW})$ of irradiation at high power densities $\left(25 \mathrm{~mW} / \mathrm{cm}^{2}\right)$ for 10 mins. This initial exploratory study found that laser treatment significantly improves behavioural rating scores (reviewed in Lapchak et al., 2012)Of note, this therapy remainings effective when initiated within 6 hours post-occlusion, which is later than any other previously effective single therapy in the same model (Lapchak et al., 2002). Importantly, this beneficial effect is measurable up to 21 days after embelisation, with no short or long term detrimental effects of R/NIR IT treatment. In a later study, the same group found that PWPulsed wave R/NIR-IT was more beneficial than CW R/NIR IT, with statistically significant increases in clinical performance at 6 hrs posttreatment $(\mathrm{p}<0.05)$, not seen with CW R/NIR-IT (Lapchak et al., 2007). This was, attributed to increased penetration of photons through the brain using the pulsed peaks (Lapchak, 2012). Lapchak and his colleagues also undertook investigations to assess the safety of combining R/NIR-IT with the only currently approved stroke therapeutic IPA. R/NIR IT was found to be safe, with R/NIR IT alone and R/NIR IT administered following IPA not adversely affecting the haemorrhage rate, haemorrhage volume or survival after large clot embelism induced stroke in New Zealand white rabbits. As such the authors recommended that a clinical trial of the tPA (Alteplase) plus R/NIR IT be conducted (Lapchak et al., 2008). 
It is well established that the core ischaemic area following occlusion of a major cerebral artery experiences rapid loss of ATP and energy production with widespread neuronal depolarization (Streeter et al., 2004). Embolisation-induced decreases of cortical ATP are attenuated by subsequent treatment with either CW R/NIR-IT or PW R/NIR-IT, although PW R/NIR-IT is more effective (Lapchak and De Taboada, 2010). Indeed PW R/NIR-IT leads to increases in cortical ATP which are significantly higher than that seen in naïve animals. These results are compatible with the hypothesis that mitochondrial cytochrome $c$ oxidase is a potent chromophore for $808 \mathrm{~nm}$ irradiation energy (Streeter et al., 2004) as described for other disease states in detail above.

\subsubsection{Pre-clinical rodent studies}

Given the therapeutic benefits for R/NIR-IT in the myocardial infarction setting, and its promising results after application in stroke models in rabbits, Oron and his colleagues studied the effects of transcranial R/NIR-IT initiated 4 and 24 hours after a middle cerebral artery occlusion (MCAO) stroke in rats (Oron et al., 2006). Using both CW and PW modes of R/NIR-IT at $7.5 \mathrm{~mW} / \mathrm{cm}^{2}$ they found that R/NIR-IT significantly attenuates neurological deficits in CW laser-treated rats, without decreasing stroke lesion volume when administered at $24 \mathrm{hrs}$, but not $4 \mathrm{hrs}$ after the onset of a stroke (Oron et al., 2006). Unlike the neuroprotective effects of R/NIR-IT demonstrated in the RSCEM, the authors found no early neuroprotective benefit of R/NIR-IT when administered at 4 hours after a stroke. Furthermore, both PW and CW R/NIR-IT have similar effects on motor outcome, although only the CW group reach significance in comparison to non-treated animals. This contrasted with an earlier study (Lapchak, 2010), the disparity perhaps attributable to the use of different experimental models and species. Interestingly, Oron et al proposed another potential 
mechanism of action of R/NIR-IT, with immunocytochemical analysis of the brain posttreatment revealing increased markers of neurogenesis (Oron et al., 2006), which may increase the functionality of neuronal circuits and promote neuronal survival within this penumbral region (Lapchak, 2010). Others have agreed in principle with this finding, noting the 2 - 4 week delay in neurological outcome improvement evident post-stroke in rat models (Detaboada et al., 2006, Shen et al., 2008). Further investigations (Detaboada et al., 2006) revealed that the location of laser treatment does not affect its efficacy, with ipsilateral, contralateral or bilateral laser treatment $\left(\mathrm{CW} 808 \mathrm{~nm}, 7.5 \mathrm{~mW} / \mathrm{cm}^{2}\right)$ administered 24 hours post-stroke efficiently improving neurological outcome. Furthermore, marked and significant improvements in neurological deficits are evident at 14, 21 and 28 days post stroke. Additional proposed mechanisms of action of R/NIR-IT in preventing neuronal death include irradiation mediated upregulation of anti-apoptotic proteins (Liang et al., 2008), heat shock proteins and antioxidant enzymes, upregulation of the neuroprotective agent transforming growth factor beta 1 (TGF- $\beta 1$ ) and suppression of the potentially neurotoxic agent nitric oxide synthase (NOS) (Leung et al., 2002). In summary, the beneficial effects of R/NIR-IT seen following stroke appear far reaching and likely achieved by attenuation of several processes in concert.

It is important to note that safety studies in rodents investigating the possible short and longterm adverse neurological effects of R/NIR-IT given at different power densities and frequencies have been conducted. A diode laser ( $808 \mathrm{~nm}$ wavelength) used to deliver power densities of $\left(7.5,75\right.$ or $\left.750 \mathrm{~mW} / \mathrm{cm}^{2}\right)$ in either $\mathrm{CW}$ or PW modes results in no discernible damage to tissue and no difference between laser-treated and control groups up to 70 days post-treatment. The only rats showing adverse neurological effects are those in the CW 750 $\mathrm{mW} / \mathrm{cm}^{2}$ group (about 100 fold increase over the current / optimal dose) (Ilic et al., 2006). 


\subsubsection{Acute ischaemic stroke clinical trials}

Two randomized double-blind clinical trials with R/NIR-IT; NeuroThera ${ }^{\circledR}$ Effectiveness and Safety Trial (NEST)-1 and NEST-2 have already been completed (Lampl et al., 2007, Zivin et al., 2009) and because pooled results indicate a clinical improvement, a third trial (NEST3) is currently underway. The phase II NEST-1 was a prospective, randomized 2:1, doubleblinded, placebo-controlled, international and multicenter trial involving 120 ischaemic stroke patients (79 in the active treatment group and 41 shams (Lampl et al., 2007)). Its primary aim was to assess the safety and efficacy of R/NIR-IT administered within 24 hours of onset of stroke symptoms. The low-energy lasers with a wavelength of $808 \mathrm{~nm}$ were applied at 20 locations on the scalp with 2 minutes of irradiation at each site, for a power density of $10 \mathrm{~mW} / \mathrm{cm}^{2}$ and energy density of $1.2 \mathrm{~J} / \mathrm{cm}^{2}$. Mean time to treatment was over 16 hours (ranging from 2 - 24 hours). The primary endpoint was the National Institutes of Health Stroke Scale (NIHSS) score collapsed into a binary outcome and the modified Rankin Scale (mRS). Briefly, patients receiving R/NIR-IT had a higher proportion of positive NIHSS and mRS outcomes than did sham-treated patients (Lampl et al., 2007) and therefore this trial provides some indication that R/NIR-IT is useful in treating the motor function deficits resulting from ischaemic strokes. Furthermore, no adverse outcomes could be attributed to the laser therapeutic procedure.

The larger phase III, NEST-2 trial was conducted in 660 stroke victims (Zivin et al., 2009). This was an acute ischaemic stroke study within 24 hours of stroke onset and excluded patients who had received thrombolytic therapy and patients with evidence of intracerebral haemorrhage. The trial results did not reach statistical significance $(\mathrm{p}=0.094)$, and were 
considered not to be positive when all patients were included. However, post-hoc subgroup analysis detects significant improvements at 90 days $(\mathrm{p}<0.04)$ in the moderately impaired stroke patients $(n=434)$ that are not evident in severely impaired patients. Pooled analysis of the 778 patients from the NEST-1 and NEST-2 trials reveals a significantly improvement in those patients treated with laser therapy (Stemer et al., 2010).

The NEST-3 clinical trial design is very similar to the NEST-2 trial and proposes to include 1000 patients within 24 hours of a stroke with an NIHSS baseline of 7-17, which is the range where beneficial effects of R/NIR-IT are seen in the NEST-1 and NEST-2 trials (Lampl et al., 2007, Zivin et al., 2009). Patients have begun to be enrolled in the NEST-3 trial with the aim of demonstrating safety and efficacy of TLT with the NeuroThera® Laser System in the treatment of subjects diagnosed with acute ischemic stroke. The initiation of the R/NIR-IT procedure must be feasible for each subject between 4.5 and 24 hours of stroke onset. The earliest treatment time of 4.5 hours, is in agreement with the recently expanded 4.5 hour therapeutic window data for tPA (Lansberg et al., 2009). Patients with infarcts located exclusively in the brainstem, cerebellum or who have small deep infarctions or massive hemispheric strokes are excluded from this trial inferring that trial enrolment may be limited to stroke patients with only small superficial cortical infarcts perhaps owing to the limitations of the CW R/NIR-IT regimen (Lapchak, 2012).

Interestingly, both the NEST-1 (Lampl et al., 2007) and NEST-2 (Zivin et al., 2009) trials used a CW treatment regimen with a power density similar to preclinical rabbit studies (Lapchak and De Taboada, 2010). This CW method is also currently in use in the NEST-3 trial, and perhaps given the fact that the CW R/NIR-IT regimen was not effective in all 
patients in the NEST-2 trial and that some preclinical studies demonstrated greater efficacy of the PW R/NIR-IT method, the CW method employed may not be optimal (Lapchak, 2012). A thorough review of the NEST trials concludes that, based upon the translational stroke results and experimental studies in other neurodegenerative conditions (De Taboada et al., 2011), laser devices in the future should incorporate PW modes to provide optimal photobiostimulation (Lapchak, 2012). Based upon the scientific justification presented in this review, there is little doubt that R/NIR-IT should be pursued as a potential non-invasive neuroprotective treatment for ischaemic stroke patients. However, the highly novel NEST trials have not taken into account many important factors such as PW utilization, dosimetry and adequate tissue coverage (Lapchak, 2012). Results from the NEST-3 trial are much anticipated and may pave the way for future studies potentially incorporating PW R/NIR-IT.

\subsection{R/NIR-IT for treatment of Parkinson's disease}

Parkinson's disease (PD) is currently the most common movement disorder worldwide, affecting $1 \%$ to $2 \%$ of the population over the age of 60 , and approximately $5 \%$ of people over the age of 85 (Alves et al., 2008). Interventions that can reduce this escalating disease burden are therefore urgently required. While regarded as a multifactorial disorder triggered by a combination of age, genetic, environmental and other factors, mitochondrial dysfunction has consistently been implicated in the disease and is widely considered as a potential unifying factor (Banerjee et al., 2009). Consistent with this, a number of experimental models of the disease are based on inhibition of mitochondrial respiratory chain function (using rotenone or 1-methyl-4-phenyl-1,2,3,6-tetrahydropyridine (MPTP)), resulting in depletion of intracellular ATP levels and generation of free radicals. Accordingly, interventions targeted at improving mitochondrial function such as R/NIR-IT are highly attractive as potential 
treatments in PD.

In a series of in vitro experiments, utilizing striatal and cortical neurones exposed to a variety of mitochondrial toxins (cyanide, rotenone and MPTP), Wong-Riley and colleagues (Liang et al., 2006, Liang et al., 2008, Ying et al., 2008) demonstrate that treatment with R/NIR irradiation $\left(670 \mathrm{~nm}\right.$ LED for $\left.80 \mathrm{sec}, 50 \mathrm{~mW} / \mathrm{cm}^{2} ; 4 \mathrm{~J} / \mathrm{cm}^{2}\right)$ increases cytochrome $c$ oxidase activity and reduces the production of reactive oxygen and nitrogen species. This is associated with a preservation of ATP content as well as a reduction in toxin-induced apoptosis. They also note in normal control tissue that the irradiation therapy increases cytochrome c oxidase activity and ATP content (Liang et al., 2008), consistent with the view that energy absorption by the mitochondrial chromophores will increase ATP production (Eells et al., 2003) by delivering protons across the mitochondrial membrane and generating a transmembrane proton-motive force (Lapchak, 2012). Increasing ATP content will presumably facilitate the ability of the neurons to combat the effect of the neurotoxins. Notably in the neurotoxin experiments, pretreatment is more effective than treatment during toxin exposure (Ying et al., 2008), presumably reflecting the advantage of having increased ATP stores prior to toxin exposure.

A subsequent series of experiments utilizing in vivo models of PD also demonstrate beneficial effects of R/NIR-IT on histological outcome measures. In a rapid onset model of MPTP challenge in mice, R/NIR-IT (670 nm LED for $90 \mathrm{sec}, 50 \mathrm{~mW} / \mathrm{cm}^{2} ; 5 \mathrm{~J} / \mathrm{cm}^{2}$ ) administered immediately after the neurotoxin increases survival of dopaminergic neurons in the substantia nigra pars compacta by $35-45 \%$ (Shaw et al., 2010). Similar results are observed in a chronic MPTP model designed to replicate the slow progressive nature of human PD. Specifically, R/NIR-IT increases the survival of dopaminergic cells in the 
substantia nigra pars compacta by up to $25 \%$ despite being administered during the 3 week survival period after the 5 week MPTP insult period (Peoples et al., 2012b). No effects are observed on other dopaminergic neurons in the periaqueductal grey matter or zona incertahypothalamus, suggesting that beneficial effects of R/NIR irradiation exposure are likely to improve motor function in PD rather than other non-motor abnormalities, such as sleep-wake cycles. Nonetheless, there are neuroprotective effects of R/NIR-IT on dopaminergic cells in the retina in both an acute and chronic MPTP based murine model of PD (Peoples et al., 2012a). In these experiments, R/NIR-IT via LED protects cells from degeneration when administered simultaneously with the toxin, as well as rescues cells when exposure is administered after the toxin (during the 3 week survival period after the 5 weeks of MPTP injections). The authors propose that the irradiation treatment stimulates release of melatonin, a well-known and powerful antioxidant that is localized to dopaminergic neurons.

Other reports suggest that the antioxidant action may also involve the normalization of levels of a number of antioxidant enzymes, including superoxide dismutase and catalase (Komel'kova et al., 2004). In their studies of PD patients, these authors also demonstrated that R/NIR-IT normalized blood levels of monoamine oxidase B, which catalyzes dopamine oxidation, in addition to superoxide dismutase and catalase. Whether the normalization of blood levels reflects the normalization of brain levels of these enzymes is unclear and requires further investigation.

While the effects of R/NIR-IT on antioxidant enzymes have been widely reported, other mechanisms of action may also play a role in improving outcome in experimental PD. R/NIR irradiation has been shown to promote the production of neurotrophic factors (Leung et al., 2002), as well as suppress inflammation, specifically the production of IL-1B, TNFaand TGF 
(De Taboada et al., 2011). Whether these reported effects account for the positive effects of R/NIR-IT on neurogenesis is currently unknown (Oron et al., 2006), although both neurotrophic factors and inflammation are widely recognized as having modulatory effects on cell survival. These and the previously discussed mechanisms of action suggest that R/NIRIT may thus represent a pleiotropic intervention that has been widely called for in the treatment of both acute and chronic conditions of the CNS.

Aside from the early studies of blood enzyme levels in PD (Komel'kova et al., 2004), few studies have investigated the effects of R/NIR-IT in a clinical setting for this disease. Nonetheless, several patents have been lodged over the past decade in an effort to facilitate such translation. A series of patents by Streeter and De Taboada (2012) (Streeter J, 2012) describe the use of R/NIR-IT to PD patients through the scalp and skull to the brain more generally, while Di Mauro and colleagues (Di Mauro TM, 2007, Toselli R, 2009) describe using an implantable probe to deliver R/NIR-IT locally to the substantia nigra. Which approach is the most efficacious is yet to be determined.

\subsection{Clinical application of R/NIR-IT}

It was originally thought that lasers (coherent, monochromatic) were essential to achieve therapeutic efficacy (Mester et al., 1985). However, the advent of LEDs (non-coherent \& with wider bandwidth), a semiconductor irradiation source that releases energy in the form of photons, provided cheaper alternatives (Posten et al., 2005) and enabled rapid uptake in a large number of human studies and randomized controlled trials (RCTs). Nevertheless, lasers currently remain the predominant irradiation source for R/NIR-IT of stroke, SCI and TBI. At last count, 112 RCTs and clinical studies have been published since 1994 on an extraordinary 
variety of conditions including osteoarthritis and rheumatoid arthritis (Christie et al., 2007, Hegedus et al., 2009) carpal tunnel syndrome (Tascioglu et al., 2010), oral mucositis for chemotherapy patients (Cauwels and Martens, 2011, Silva et al., 2011), neck pain (Chow et al., 2009) and leg ulcers (Kaviani et al., 2011). By contrast, only a small number of RCTs have been published for neurological conditions (Table 2). Efficacy has been reported for stroke (Lampl et al., 2007, Stemer et al., 2010, Zivin et al., 2009), as described above, along with 3 case reports for TBI (Naeser et al., 2011, Nawashiro et al., 2012) and a study on major depression (Schiffer et al., 2009). However, across the broad range of conditions that have been examined, clinical efficacy is not always clear cut with many reports showing no benefit, for example oral mucositis (Gouvea de Lima et al., 2012), leg ulcers (Kokol et al., 2005), stroke (Zivin et al., 2009), pain and joint disorders (Bjordal et al., 2003) and tinnitus (Teggi et al., 2009). Information from the far larger number of RCTs and clinical studies for non-neurological conditions may offer insights into published studies, current RCTs on neurological conditions and aid in the optimal design of low irradiation laser therapy treatments for a broader range of neurological dysfunctions.

Regardless of the irradiation source (laser or LED), dosimetry of R/NIR-IT is highly complex because a wide range of parameters can be altered, including wavelength, irradiance, pulse structure, coherence and polarization, as well as the actual dose delivered, which can involve variations in energy, energy density, irradiation time and treatment interval in addition to the site of the injury or disease (Chung et al., 2012). Highly variable dosimetry between studies makes direct comparison difficult if not impossible (Jenkins and Carroll, 2011) and has contributed to lack of consensus as well as scepticism regarding efficacy. 
Indeed, for conditions that have been widely studied, 3 Cochrane Database Systematic Reviews reveal conflicting data for osteoarthritis (5 RCTs, 112 patients (Brosseau et al., 2003b)), some benefit for rheumatoid arthritis (5 RCTs, 222 patients (Brosseau et al., 2003a)) and insufficient data to draw conclusions for low-back pain (6 RCTs, 318 patients (YousefiNooraie et al., 2008)). The Cochrane Reviews points to a lack of standardized, validated outcomes, lack of harmonized dose calculation and an absence of data on how effectiveness is affected by wavelength, treatment duration, dosage and site of application. The recent call to harmonise reporting of R/NIR-IT suggests mandatory inclusion of 8 beam parameters (wavelength, power, irradiation time, beam area, pulse parameters, anatomical location, number of treatments and the interval between treatments) as well as other details for the reporting of both clinical and laboratory studies (Jenkins and Carroll, 2011).

An interrelated dosimetry issue is that of the biphasic dose response in biological tissue which is observed both in vitro and in vivo and which is characterised by initial efficacy as irradiance and time are increased, followed by a decline, no effect or even inhibition (Chung et al., 2012, Huang et al., 2011). The mechanism underpinning the biphasic response is thought to involve reactive oxygen and nitrogen species that are normally produced at low levels in healthy cells and are key signalling transcription factors (Leonarduzzi et al., 2011, Shi and Gibson, 2007). Low R/NIR-IT doses result in cellular events such as proliferation, migration and neurite outgrowth in vitro as well as improvements in various conditions in vivo such as wound healing, cardiac infarction and arthritis. However, higher doses, which result in excessive ROS, show reduced effects or inhibition (reviewed (Hashmi et al., 2010, Huang et al., 2011)). 
In this context and as described earlier, Huang et al., (Huang et al., 2011) have shown in a mouse pneumatic cortical impact model that delivering a single dose $\left(36 \mathrm{~J} / \mathrm{cm}^{2} 810 \mathrm{~nm}\right.$ laser at $50 \mathrm{~mW} / \mathrm{cm}^{2}$ ) over 12 minutes is beneficial on the neurological severity score (NSS) but that a 10 -fold greater dose $\left(360 \mathrm{~J} / \mathrm{cm}^{2} 810 \mathrm{~nm}\right.$ laser at $\left.500 \mathrm{~mW} / \mathrm{cm}^{2}\right)$ also delivered over 12 minutes results in worse outcomes compared to no treatment. Intriguingly, delivering the same low dose daily for 14 days starting at $4 \mathrm{~h}$ after injury results in slight improvement at 4 days compared to the single dose but, between $14-28$ days, NSS is no better than no treatment and shows a trend to worse outcome. The biphasic tissue response cautions that "more is not necessarily better". As we argue above, this conclusion is supported by the fact that only extremely low irradiation doses are sufficient to elicit biophysical changes at the cellular level. Nevertheless, the almost complete lack of adverse / serious adverse events reported in clinical trials argues for continued clinical investigation of R/NIR-IT.

In addition to relative safety, the non-invasive nature of R/NIR-IT has undoubtedly contributed to its relatively rapid uptake in clinical trials. For example, R/NIR laser therapy was developed and patented between 1997 and 2001, with the first clinical trial in acute ischaemic stroke published in 2007 (NEST-1) (Lampl et al., 2007). This was followed by NEST-2 (Zivin et al., 2009), an analysis of pooled data from NEST-1 and NEST-2 (Stemer et al., 2010) and with NEST-3 now underway (Lapchak, 2010). With respect to the future, there are 10 currently registered RCTs for R/NIR-IT in neurological conditions, one of which is published (NEST-2). The hope is that these will yield data that avoid the shortcomings highlighted by the Cochrane Reviews on R/NIR-IT in other conditions (Brosseau et al., 2003a, Brosseau et al., 2003b, Yousefi-Nooraie et al., 2008) and progress the field regarding the use of R/NIR-IT. 
Acknowledgements: This work was supported by the Neurotrauma Research Program (Western Australia). Prof. Dunlop is a Principal Research Fellow of the NH\&MRC, Australia (Grant ID: APP1002347). A/Prof. Nathan Hart would like to acknowledge the support of Prof. Shaun Collin. 


\section{References}

1. Ad, N. and U. Oron. (2001). Impact of low level laser irradiation on infarct size in the rat following myocardial infarction. Int J Cardiol 80(2-3), p. 109-16.

2. Albarracin, R., J. Eells, and K. Valter. (2011). Photobiomodulation protects the retina from light-induced photoreceptor degeneration. Invest Ophthalmol Vis Sci 52(6), p. 3582-92.

3. Albarracin, R. and K. Valter. (2012a). $670 \mathrm{~nm}$ Red Light Preconditioning Supports Muller Cell Function: Evidence from the White Light-induced Damage Model in the Rat Retina(dagger). Photochem Photobiol.

4. Albarracin, R.S. and K. Valter. (2012b). Treatment with 670-nm light protects the cone photoreceptors from white light-induced degeneration. Adv Exp Med Biol 723, p. 121-8.

5. Alves, G., et al. (2008). Epidemiology of Parkinson's disease. J Neurol 255 Suppl 5, p. 18-32.

6. Ando, T., et al. (2011). Comparison of therapeutic effects between pulsed and continuous wave 810-nm wavelength laser irradiation for traumatic brain injury in mice. PLoS One 6(10), p. e26212.

7. Ankri, R., R. Lubart, and H. Taitelbaum. (2010). Estimation of the Optimal Wavelengths for Laser-Induced Wound Healing. Lasers in Surgery and Medicine 42(8), p. 760-764.

8. Assia, E., et al. (1989). Temporal parameters of low energy laser irradiation for optimal delay of post-traumatic degeneration of rat optic nerve. Brain Res 476(2), p. 205-12.

9. Balaratnasingam, C., et al. (2009). Heterogeneous distribution of axonal cytoskeleton proteins in the human optic nerve. Invest Ophthalmol Vis Sci 50(6), p. 2824-38. 
10. Ball, K.A., P.R. Castello, and R.O. Poyton. (2011). Low intensity light stimulates nitrite-dependent nitric oxide synthesis but not oxygen consumption by cytochrome c oxidase: Implications for phototherapy. J Photochem Photobiol B 102(3), p. 182-91.

11. Banerjee, R., et al. (2009). Mitochondrial dysfunction in the limelight of Parkinson's disease pathogenesis. Biochim Biophys Acta 1792(7), p. 651-63.

12. Baptiste, D.C. and M.G. Fehlings. (2006). Pharmacological approaches to repair the injured spinal cord. J Neurotrauma 23(3-4), p. 318-34.

13. Biron, K.E., et al. (2011). Amyloid triggers extensive cerebral angiogenesis causing blood brain barrier permeability and hypervascularity in Alzheimer's disease. PloS one 6(8), p. e23789.

14. Bjordal, J.M., et al. (2003). A systematic review of low level laser therapy with location-specific doses for pain from chronic joint disorders. Aust J Physiother 49(2), p. 107-16.

15. Brambilla, R., V. Bracchi-Ricard, and J.R. Bethea. (2006). Chapter 13. Cytokines in Brain and Spinal Cord Injury in "Cytokines and the CNS"(Eds. Ransohoff, R.M. and Benveniste, E.N., CRC Publications), p. 299-326.

16. Brosseau, L., et al. (2003a). Transcutaneous electrical nerve stimulation (TENS) for the treatment of rheumatoid arthritis in the hand. Cochrane Database Syst Rev (3), p. CD004377.

17. Brosseau, L., et al. (2003b). Low level laser therapy (Classes I, II and III) for treating osteoarthritis. Cochrane Database Syst Rev (2), p. CD002046.

18. Buki, A., D.O. Okonkwo, and J.T. Povlishock. (1999). Postinjury cyclosporin A administration limits axonal damage and disconnection in traumatic brain injury. $\mathrm{J}$ Neurotrauma 16(6), p. 511-21. 
19. Byrnes, K.R., et al. (2005). Light promotes regeneration and functional recovery and alters the immune response after spinal cord injury. Lasers Surg Med 36(3), p. 17185.

20. Camello-Almaraz, M.C., et al. (2006). Mitochondrial production of oxidants is necessary for physiological calcium oscillations. J Cell Physiol 206(2), p. 487-94.

21. Carter, K. and G. Palmer. (1982). Models of the two heme centers in cytochrome oxidase. The optical properties of cytochrome a and a3. J Biol Chem 257(22), p. 13507-14.

22. Cauwels, R.G. and L.C. Martens. (2011). Low level laser therapy in oral mucositis: a pilot study. European archives of paediatric dentistry : official journal of the European Academy of Paediatric Dentistry 12(2), p. 118-23.

23. Cheong, W.F., S.A. Prahl, and A.J. Welch. (1990). A Review of the OpticalProperties of Biological Tissues. Ieee Journal of Quantum Electronics 26(12), p. 2166-2185.

24. Chow, R.T., et al. (2009). Efficacy of low-level laser therapy in the management of neck pain: a systematic review and meta-analysis of randomised placebo or activetreatment controlled trials. Lancet 374(9705), p. 1897-908.

25. Christie, A., et al. (2007). Effectiveness of nonpharmacological and nonsurgical interventions for patients with rheumatoid arthritis: an overview of systematic reviews. Physical Therapy 87(12), p. 1697-715.

26. Chung, H., et al. (2012). The nuts and bolts of low-level laser (light) therapy. Ann Biomed Eng 40(2), p. 516-33.

27. Curcio, C.A., et al. (1990). Human photoreceptor topography. J Comp Neurol 292(4), p. 497-523. 
28. De Taboada, L., et al. (2011). Transcranial laser therapy attenuates amyloid-beta peptide neuropathology in amyloid-beta protein precursor transgenic mice. J Alzheimers Dis 23(3), p. 521-35.

29. Demontis, G.C., B. Longoni, and P.L. Marchiafava. (2002). Molecular steps involved in light-induced oxidative damage to retinal rods. Invest Ophthalmol Vis Sci 43(7), p. 2421-7.

30. Desai Bradaric, B., et al. (2012). Evidence for angiogenesis in Parkinson's disease, incidental Lewy body disease, and progressive supranuclear palsy. J Neural Transm 119(1), p. 59-71.

31. Detaboada, L., et al. (2006). Transcranial application of low-energy laser irradiation improves neurological deficits in rats following acute stroke. Lasers Surg Med 38(1), p. 70-3.

32. Di Mauro TM, A.M., Holy C, Lilienfeld S, Sutton JK, Ward M. (2007). Red light implant for treating Parkinson's Disease: USA.

33. Eells, J.T., et al. (2003). Therapeutic photobiomodulation for methanol-induced retinal toxicity. Proc Natl Acad Sci U S A 100(6), p. 3439-44.

34. Eells, J.T., et al. (2004). Mitochondrial signal transduction in accelerated wound and retinal healing by near-infrared light therapy. Mitochondrion 4(5-6), p. 559-67.

35. Eichler, J., J. Knof, and H. Lenz. (1977). Measurements on Depth of Penetration of Light (0.35-1.0mu-M) in Tissue. Radiation and Environmental Biophysics 14(3), p. 239-242.

36. Firbank, M., et al. (1993). Measurement of the Optical-Properties of the Skull in the Wavelength Range 650-950 Nm. Physics in Medicine and Biology 38(4), p. 503-510. 
37. Fitzgerald, M., et al. (2010). Near infrared light reduces oxidative stress and preserves function in CNS tissue vulnerable to secondary degeneration following partial transection of the optic nerve. J Neurotrauma 27(11), p. 2107-19.

38. Gouvea de Lima, A., et al. (2012). Oral mucositis prevention by low-level laser therapy in head-and-neck cancer patients undergoing concurrent chemoradiotherapy: a phase III randomized study. International journal of radiation oncology, biology, physics $82(1)$, p. $270-5$.

39. Hartz, A.M., et al. (2012). Amyloid-beta contributes to blood-brain barrier leakage in transgenic human amyloid precursor protein mice and in humans with cerebral amyloid angiopathy. Stroke 43(2), p. 514-23.

40. Hashmi, J.T., et al. (2010). Role of low-level laser therapy in neurorehabilitation. PM R 2(12 Suppl 2), p. S292-305.

41. Hebeda, K.M., et al. (1994). Light propagation in the brain depends on nerve fiber orientation. Neurosurgery 35(4), p. 720-2; discussion 722-4.

42. Hegedus, B., et al. (2009). The effect of low-level laser in knee osteoarthritis: a double-blind, randomized, placebo-controlled trial. Photomed Laser Surg 27(4), p. 577-84.

43. Hollyfield, J.G., et al. (2008). Oxidative damage-induced inflammation initiates agerelated macular degeneration. Nat Med 14(2), p. 194-8.

44. Hom, J., et al. (2011). Blood-brain barrier permeability assessed by perfusion CT predicts symptomatic hemorrhagic transformation and malignant edema in acute ischemic stroke. AJNR Am J Neuroradiol 32(1), p. 41-8.

45. Howards, R., Holmes PA, Siddiqui A, Treacher D, Tsiropoulos I, Koutroumanidis M. (2012). Hypoxic-ischemic brain injury: imaging and neurophysiological abnormalities related to outcome. Quarterly Journal of Medicine 105 p. 551-561. 
46. Huang, Y.Y., et al. (2012). Transcranial low level laser (light) therapy for traumatic brain injury. J Biophotonics.

47. Huang, Y.Y., et al. (2011). Biphasic dose response in low level light therapy - an update. Dose Response 9(4), p. 602-18.

48. Ilic, S., et al. (2006). Effects of power densities, continuous and pulse frequencies, and number of sessions of low-level laser therapy on intact rat brain. Photomed Laser Surg 24(4), p. 458-66.

49. Ishiguro, M., K. Ikeda, and K. Tomita. (2010). Effect of near-infrared light-emitting diodes on nerve regeneration. J Orthop Sci 15(2), p. 233-9.

50. Iwamura, A., et al. (2012). Diffuse vascular injury: convergent-type hemorrhage in the supratentorial white matter on susceptibility-weighted image in cases of severe traumatic brain damage. Neuroradiology 54(4), p. 335-43.

51. Jenkins, P.A. and J.D. Carroll. (2011). How to report low-level laser therapy (LLLT)/photomedicine dose and beam parameters in clinical and laboratory studies. Photomed Laser Surg 29(12), p. 785-7.

52. Johnson, V.E., W. Stewart, and D.H. Smith. (2012). Axonal pathology in traumatic brain injury. Exp Neurol.

53. Karu, T. (1989). Photobiology of Low-Power Laser Effects. Health Physics 56(5), p. 691-704.

54. Karu, T. (1999). Primary and secondary mechanisms of action of visible to near-IR radiation on cells. J Photochem Photobiol B 49(1), p. 1-17.

55. Karu, T.I. and S.F. Kolyakov. (2005). Exact action spectra for cellular responses relevant to phototherapy. Photomed Laser Surg 23(4), p. 355-61. 
56. Karu, T.I., et al. (2005). Absorption measurements of a cell monolayer relevant to phototherapy: reduction of cytochrome $\mathrm{c}$ oxidase under near IR radiation. J Photochem Photobiol B 81(2), p. 98-106.

57. Karu, T.I., et al. (2008). Absorption measurements of cell monolayers relevant to mechanisms of laser phototherapy: reduction or oxidation of cytochrome c oxidase under laser radiation at $632.8 \mathrm{~nm}$. Photomed Laser Surg 26(6), p. 593-9.

58. Kaviani, A., et al. (2011). A randomized clinical trial on the effect of low-level laser therapy on chronic diabetic foot wound healing: a preliminary report. Photomed Laser Surg 29(2), p. 109-14.

59. Keane, R.W., A.R. Davis, and W.D. Dietrich. (2006). Inflammatory and apoptotic signaling after spinal cord injury. J Neurotrauma 23(3-4), p. 335-44.

60. Khuman, J., et al. (2012). Low-level laser light therapy improves cognitive deficits and inhibits microglial activation after controlled cortical impact in mice. J Neurotrauma 29(2), p. 408-17.

61. Kokkinopoulos, I., et al. (2012). Age-related retinal inflammation is reduced by 670 nm light via increased mitochondrial membrane potential. Neurobiol Aging.

62. Kokol, R., et al. (2005). [Venous leg ulcers: no improvement of wound healing with 685-nm low level laser therapy. Randomised, placebo-controlled, double-blind study]. Der Hautarzt; Zeitschrift fur Dermatologie, Venerologie, und verwandte Gebiete 56(6), p. 570-5.

63. Komel'kova, L.V., et al. (2004). [Biochemical and immunological induces of the blood in Parkinson's disease and their correction with the help of laser therapy]. Patol Fiziol Eksp Ter (1), p. 15-8.

64. Kowaltowski, A.J., et al. (2009). Mitochondria and reactive oxygen species. Free Radic Biol Med 47(4), p. 333-43. 
65. Lampl, Y., et al. (2007). Infrared laser therapy for ischemic stroke: a new treatment strategy: results of the NeuroThera Effectiveness and Safety Trial-1 (NEST-1). Stroke 38(6), p. 1843-9.

66. Lansberg, M.G., E. Bluhmki, and V.N. Thijs. (2009). Efficacy and safety of tissue plasminogen activator 3 to 4.5 hours after acute ischemic stroke: a metaanalysis. Stroke 40(7), p. 2438-41.

67. Lapchak, P.A. (2010). Taking a light approach to treating acute ischemic stroke patients: transcranial near-infrared laser therapy translational science. Ann Med 42(8), p. 576-86.

68. Lapchak, P.A. (2012). Transcranial near-infrared laser therapy applied to promote clinical recovery in acute and chronic neurodegenerative diseases. Expert Rev Med Devices 9(1), p. 71-83.

69. Lapchak, P.A., et al. (2002). Neuroprotective effects of the spin trap agent disodium[(tert-butylimino)methyl]benzene-1,3-disulfonate N-oxide (generic NXY-059) in a rabbit small clot embolic stroke model: combination studies with the thrombolytic tissue plasminogen activator. Stroke 33(5), p. 1411-5.

70. Lapchak, P.A. and L. De Taboada. (2010). Transcranial near infrared laser treatment (NILT) increases cortical adenosine-5'-triphosphate (ATP) content following embolic strokes in rabbits. Brain Res 1306, p. 100-5.

71. Lapchak, P.A., et al. (2008). Safety profile of transcranial near-infrared laser therapy administered in combination with thrombolytic therapy to embolized rabbits. Stroke 39(11), p. 3073-8.

72. Lapchak, P.A., et al. (2007). Transcranial near-infrared light therapy improves motor function following embolic strokes in rabbits: an extended therapeutic window study 
using continuous and pulse frequency delivery modes. Neuroscience $148(4)$, p. $907-$ 14.

73. Lenz, P. (1999). Fluorescence measurement in thick tissue layers by linear or nonlinear long-wavelength excitation. Applied Optics 38(16), p. 3662-3669.

74. Leonarduzzi, G., et al. (2011). New insights into redox-modulated cell signaling. Curr Pharm Des 17(36), p. 3994-4006.

75. Leung, M.C., et al. (2002). Treatment of experimentally induced transient cerebral ischemia with low energy laser inhibits nitric oxide synthase activity and up-regulates the expression of transforming growth factor-beta 1. Lasers Surg Med 31(4), p. 283-8.

76. Liang, H.L., et al. (2006). Photobiomodulation partially rescues visual cortical neurons from cyanide-induced apoptosis. Neuroscience 139(2), p. 639-49.

77. Liang, H.L., et al. (2008). Near-infrared light via light-emitting diode treatment is therapeutic against rotenone- and 1-methyl-4-phenylpyridinium ion-induced neurotoxicity. Neuroscience 153(4), p. 963-74.

78. Lim, J., et al. (2009). Effects of low-level light therapy on hepatic antioxidant defense in acute and chronic diabetic rats. J Biochem Mol Toxicol 23(1), p. 1-8.

79. Lim, J., et al. (2010). Effects of low-level light therapy on streptozotocin-induced diabetic kidney. J Photochem Photobiol B 99(2), p. 105-10.

80. Liu, X.Z., et al. (1997). Neuronal and glial apoptosis after traumatic spinal cord injury. J Neurosci 17(14), p. 5395-406.

81. Mason, M.G., et al. (2006). Nitric oxide inhibition of respiration involves both competitive (heme) and noncompetitive (copper) binding to cytochrome c oxidase. Proc Natl Acad Sci U S A 103(3), p. 708-13.

82. Maxwell, W.L., et al. (2003). Post-acute alterations in the axonal cytoskeleton after traumatic axonal injury. J Neurotrauma 20(2), p. 151-68. 
83. McCarthy, T.J., et al. (2010). Long-term safety of single and multiple infrared transcranial laser treatments in Sprague-Dawley rats. Photomed Laser Surg 28(5), p. $663-7$.

84. Medalha, C.C., et al. (2010). Comparison of the effects of electrical field stimulation and low-level laser therapy on bone loss in spinal cord-injured rats. Photomed Laser Surg 28(5), p. 669-74.

85. Mester, E., A.F. Mester, and A. Mester. (1985). The biomedical effects of laser application. Lasers Surg Med 5(1), p. 31-9.

86. Mitchell, U.H., et al. (2011). Restless legs syndrome and near-infrared light: An alternative treatment option. Physiother Theory Pract 27(5), p. 345-51.

87. Mitra, S. and T.H. Foster. (2004). Carbogen breathing significantly enhances the penetration of red light in murine tumours in vivo. Phys Med Biol 49(10), p. 1891904.

88. Moftakhar, P., et al. (2010). Aquaporin expression in the brains of patients with or without cerebral amyloid angiopathy. J Neuropathol Exp Neurol 69(12), p. 1201-9.

89. Moreira, M.S., et al. (2009). Effect of phototherapy with low intensity laser on local and systemic immunomodulation following focal brain damage in rat. $\mathrm{J}$ Photochem Photobiol B 97(3), p. 145-51.

90. Muller, P.J. and B.C. Wilson. (1986). An Update on the Penetration Depth of $630 \mathrm{Nm}$ Light in Normal and Malignant Human-Brain Tissue Invivo. Physics in Medicine and Biology 31(11), p. 1295-1297.

91. Multipleauthors. (2001). A randomized, placebo-controlled, clinical trial of high-dose supplementation with vitamins $\mathrm{C}$ and $\mathrm{E}$, beta carotene, and zinc for age-related macular degeneration and vision loss: AREDS report no. 8. Arch Ophthalmol. 119(10), p. 1439-52. 
92. Naeser, M.A., et al. (2011). Improved cognitive function after transcranial, lightemitting diode treatments in chronic, traumatic brain injury: two case reports. Photomed Laser Surg 29(5), p. 351-8.

93. Nashmi, R. and M.G. Fehlings. (2001). Mechanisms of axonal dysfunction after spinal cord injury: with an emphasis on the role of voltage-gated potassium channels. Brain Res Brain Res Rev 38(1-2), p. 165-91.

94. Natoli, R., et al. (2010). Gene and noncoding RNA regulation underlying photoreceptor protection: microarray study of dietary antioxidant saffron and photobiomodulation in rat retina. Mol Vis 16 , p. 1801-22.

95. Nawashiro, H., et al. (2012). Focal increase in cerebral blood flow after treatment with near-infrared light to the forehead in a patient in a persistent vegetative state. Photomed Laser Surg 30(4), p. 231-3.

96. Neupane, J., et al. (2010). Effect of light emitting diodes in the photodynamic therapy of rheumatoid arthritis. Photodiagnosis and Photodynamic Therapy 7(1), p. 44-49.

97. Oddo, M., et al. (2011). Brain hypoxia is associated with short-term outcome after severe traumatic brain injury independently of intracranial hypertension and low cerebral perfusion pressure. Neurosurgery 69(5), p. 1037-45; discussion 1045.

98. Oron, A., et al. (2006). Low-level laser therapy applied transcranially to rats after induction of stroke significantly reduces long-term neurological deficits. Stroke 37(10), p. 2620-4.

99. Oron, A., et al. (2007). Low-level laser therapy applied transcranially to mice following traumatic brain injury significantly reduces long-term neurological deficits. J Neurotrauma 24(4), p. 651-6. 
100. Oron, A., et al. (2012). Near infrared transcranial laser therapy applied at various modes to mice following traumatic brain injury significantly reduces long-term neurological deficits. J Neurotrauma 20(29), p. 401-7.

101. Oron, U., et al. (2001). Attenuation of infarct size in rats and dogs after myocardial infarction by low-energy laser irradiation. Lasers Surg Med 28(3), p. 204-11.

102. Park, E., A.A. Velumian, and M.G. Fehlings. (2004). The role of excitotoxicity in secondary mechanisms of spinal cord injury: a review with an emphasis on the implications for white matter degeneration. J Neurotrauma 21(6), p. 754-74.

103. Parrish, J.A. (1981). New concepts in therapeutic photomedicine: photochemistry, optical targeting and the therapeutic window. J Invest Dermatol 77(1), p. 45-50.

104. Peng, T.I. and M.J. Jou. (2010). Oxidative stress caused by mitochondrial calcium overload. Ann N Y Acad Sci 1201, p. 183-8.

105. Peoples, C., et al. (2012a). Survival of Dopaminergic Amacrine Cells after NearInfrared Light Treatment in MPTP-Treated Mice. ISRN Neurol 2012, p. 850150.

106. Peoples, C., et al. (2012b). Photobiomodulation enhances nigral dopaminergic cell survival in a chronic MPTP mouse model of Parkinson's disease. Parkinsonism Relat Disord 18(5), p. 469-76.

107. Posten, W., et al. (2005). Low-level laser therapy for wound healing: mechanism and efficacy. Dermatol Surg 31(3), p. 334-40.

108. Profio, A.E. (1989). Light Transport in Tissue. Applied Optics 28(12), p. 2216-2221.

109. Profyris, C., et al. (2004). Degenerative and regenerative mechanisms governing spinal cord injury. Neurobiol Dis 15(3), p. 415-36.

110. Qu, C., et al. (2010). Near-infrared light protect the photoreceptor from light-induced damage in rats. Adv Exp Med Biol 664, p. 365-74. 
111. Quirk, B.J., et al. (2012). Near-Infrared Photobiomodulation in an Animal Model of Traumatic Brain Injury: Improvements at the Behavioral and Biochemical Levels. Photomed Laser Surg.

112. Quirk, B.J. and H.T. Whelan. (2011). Near-infrared irradiation photobiomodulation: the need for basic science. Photomedicine and Laser Surgery 29(3), p. 143-144.

113. Rochkind, S., S. Geuna, and A. Shainberg. (2009). Chapter 25: Phototherapy in peripheral nerve injury: effects on muscle preservation and nerve regeneration. Int Rev Neurobiol 87, p. 445-64.

114. Rodieck, R.W., (1998). The First Steps in Seeing: Sinauer Associates Inc.

115. Rodriguez-Baeza, A., et al. (2003). Morphological features in human cortical brain microvessels after head injury: a three-dimensional and immunocytochemical study. Anat Rec A Discov Mol Cell Evol Biol 273(1), p. 583-93.

116. Rojas, J.C., et al. (2008). Neuroprotective effects of near-infrared light in an in vivo model of mitochondrial optic neuropathy. J Neurosci 28(50), p. 13511-21.

117. Rutar, M., et al. (2011). Early focal expression of the chemokine Ccl2 by Muller cells during exposure to damage-inducing bright continuous light. Invest Ophthalmol Vis Sci 52(5), p. 2379-88.

118. Rutar, M., J.M. Provis, and K. Valter. (2010). Brief exposure to damaging light causes focal recruitment of macrophages, and long-term destabilization of photoreceptors in the albino rat retina. Curr Eye Res 35(7), p. 631-43.

119. Sandeman, D., Mills T., Brown S.G. (1986). Enhancement of light penetration by white matter tracts in the normal mouse brain. Lasers in Surgery and Medicine 3, p. 47. 
120. Schiffer, F., et al. (2009). Psychological benefits 2 and 4 weeks after a single treatment with near infrared light to the forehead: a pilot study of 10 patients with major depression and anxiety. Behav Brain Funct 5, p. 46.

121. Segura, T., S. Calleja, and J. Jordan. (2008). Recommendations and treatment strategies for the management of acute ischemic stroke. Expert Opin Pharmacother 9(7), p. 1071-85.

122. Sekhon, L.H. and M.G. Fehlings. (2001). Epidemiology, demographics, and pathophysiology of acute spinal cord injury. Spine 26(24 Suppl), p. S2-12.

123. Seme, M.T., et al. (1999). Formate-induced inhibition of photoreceptor function in methanol intoxication. J Pharmacol Exp Ther 289(1), p. 361-70.

124. Shaw, V.E., et al. (2010). Neuroprotection of midbrain dopaminergic cells in MPTPtreated mice after near-infrared light treatment. J Comp Neurol 518(1), p. 25-40.

125. Shen, J., et al. (2008). Neurogenesis after primary intracerebral hemorrhage in adult human brain. J Cereb Blood Flow Metab 28(8), p. 1460-8.

126. Shen, J., et al. (2005). Oxidative damage is a potential cause of cone cell death in retinitis pigmentosa. J Cell Physiol 203(3), p. 457-64.

127. Shi, Q. and G.E. Gibson. (2007). Oxidative stress and transcriptional regulation in Alzheimer disease. Alzheimer Dis Assoc Disord 21(4), p. 276-91.

128. Silva, G.B., et al. (2011). The prevention of induced oral mucositis with low-level laser therapy in bone marrow transplantation patients: a randomized clinical trial. Photomed Laser Surg 29(1), p. 27-31.

129. Stemer, A.B., B.N. Huisa, and J.A. Zivin. (2010). The evolution of transcranial laser therapy for acute ischemic stroke, including a pooled analysis of NEST-1 and NEST2. Curr Cardiol Rep 12(1), p. 29-33. 
130. Sterenborg, H., Van Gemert, MJC, Kamphorst, W, Wolbers, JG, Hogervorst, W. (1989). The spectral dependence of optical properties of human brain. Lasers in Medical Science 4 p. 221-227.

131. Stolik, S., et al. (2000). Measurement of the penetration depths of red and near infrared light in human "ex vivo" tissues. Journal of Photochemistry and Photobiology B-Biology 57(2-3), p. 90-93.

132. Stone, J., et al. (1999). Mechanisms of photoreceptor death and survival in mammalian retina. Prog Retin Eye Res 18(6), p. 689-735.

133. Streeter, J., L. De Taboada, and U. Oron. (2004). Mechanisms of action of light therapy for stroke and acute myocardial infarction. Mitochondrion 4(5-6), p. 569-76.

134. Streeter J, D.T.L. (2012). Low level light therapy for enhancement of neurologic function: USA.

135. Sutherland, J.C. (2002). Biological effects of polychromatic light. Photochem Photobiol 76(2), p. 164-70.

136. Svaasand, L.O. and R. Ellingsen. (1983). Optical-Properties of Human-Brain. Photochemistry and Photobiology 38(3), p. 293-299.

137. Sykova, E. and L. Vargova. (2008). Extrasynaptic transmission and the diffusion parameters of the extracellular space. Neurochem Int 52(1-2), p. 5-13.

138. Tang-Schomer, M.D., et al. (2012). Partial interruption of axonal transport due to microtubule breakage accounts for the formation of periodic varicosities after traumatic axonal injury. Exp Neurol 233(1), p. 364-72.

139. Tascioglu, F., et al. (2010). Short-term effectiveness of ultrasound therapy in knee osteoarthritis. J Int Med Res 38(4), p. 1233-42.

140. Teggi, R., et al. (2009). Transmeatal low-level laser therapy for chronic tinnitus with cochlear dysfunction. Audiol Neurootol 14(2), p. 115-20. 
141. Topakian, R., et al. (2010). Blood-brain barrier permeability is increased in normalappearing white matter in patients with lacunar stroke and leucoaraiosis. J Neurol Neurosurg Psychiatry 81(2), p. 192-7.

142. Toselli R, D.M.T., Fisher M. (2009). Endoscopic delivery of red/NIR light to the substantia nigra to treat Parkinson's disease: USA.

143. Tretter, L., et al. (2007). Stimulation of $\mathrm{H}(2) \mathrm{O}(2)$ generation by calcium in brain mitochondria respiring on alpha-glycerophosphate. J Neurosci Res 85(15), p. 3471-9.

144. Tsukahara, H., et al. (2004). Oxidative stress in neonates: evaluation using specific biomarkers. Life Sci 75(8), p. 933-8.

145. von Bussmann, K.A., L.J. Garey, and L.S. Jen. (1993). Injury-resistant retinal ganglion cells that are rich in cytochrome oxidase. Neuroreport 4(3), p. 247-50.

146. Wan, S., et al. (1981). Transmittance of Nonionizing Radiation in Human-Tissues. Photochemistry and Photobiology 34(6), p. 679-681.

147. Whelan, H.T., et al. (2003). Effect of NASA light-emitting diode irradiation on molecular changes for wound healing in diabetic mice. J Clin Laser Med Surg 21(2), p. 67-74.

148. Whelan, H.T., et al. (2001). Effect of NASA light-emitting diode irradiation on wound healing. J Clin Laser Med Surg 19(6), p. 305-14.

149. Winkler, B.S. (1981). Glycolytic and oxidative metabolism in relation to retinal function. J Gen Physiol 77(6), p. 667-92.

150. Wong-Riley, M.T., et al. (2001). Light-emitting diode treatment reverses the effect of TTX on cytochrome oxidase in neurons. Neuroreport 12(14), p. 3033-7.

151. Wong-Riley, M.T., et al. (2005). Photobiomodulation directly benefits primary neurons functionally inactivated by toxins: role of cytochrome c oxidase. J Biol Chem 280(6), p. 4761-71. 
152. Wu, Q., et al. (2012). Low-level laser therapy for closed-head traumatic brain injury in mice: effect of different wavelengths. Lasers Surg Med 44(3), p. 218-26.

153. Wu, X., et al. (2009). $810 \mathrm{~nm}$ Wavelength light: an effective therapy for transected or contused rat spinal cord. Lasers Surg Med 41(1), p. 36-41.

154. Ying, R., et al. (2008). Pretreatment with near-infrared light via light-emitting diode provides added benefit against rotenone- and MPP+-induced neurotoxicity. Brain Res 1243, p. $167-73$.

155. Yousefi-Nooraie, R., et al. (2008). Low level laser therapy for nonspecific low-back pain. Cochrane Database Syst Rev (2), p. CD005107.

156. Yu, D.Y., et al. (1999). Intraretinal oxygen distribution in the rat with graded systemic hyperoxia and hypercapnia. Invest Ophthalmol Vis Sci 40(9), p. 2082-7.

157. Yu, W., et al. (1997). Photomodulation of oxidative metabolism and electron chain enzymes in rat liver mitochondria. Photochem Photobiol 66(6), p. 866-71.

158. Zivin, J.A., et al. (2009). Effectiveness and safety of transcranial laser therapy for acute ischemic stroke. Stroke 40(4), p. 1359-64. 
Table 1 A summary of R/NIR-IT for treatment of neurotrauma and neurodegenerative disease.

\begin{tabular}{|c|c|c|c|c|c|c|c|c|}
\hline Study & $\begin{array}{l}\text { In vitro: } \\
\text { cell type, } \\
\text { species } \\
\end{array}$ & $\begin{array}{l}\text { In vivo: } \\
\text { model, } \\
\text { species }\end{array}$ & \begin{tabular}{|l} 
Light source \\
\end{tabular} & $\begin{array}{l}\text { Wave- } \\
\text { length }\end{array}$ & $\begin{array}{l}\text { Intensity, } \\
\text { density }\end{array}$ & $\begin{array}{l}\text { Treatment } \\
\text { duration }\end{array}$ & $\begin{array}{l}\text { Trial } \\
\text { length }\end{array}$ & Key outcomes \\
\hline \multicolumn{9}{|l|}{$\begin{array}{l}\text { Retinal } \\
\text { degeneration }\end{array}$} \\
\hline $\begin{array}{l}\text { Eells et al., } 2003 \\
\text { Proc Natl Acad Sci } \\
18 ; 100(6) \text { p } 3439\end{array}$ & NA & $\begin{array}{l}\text { Methanol } \\
\text { toxicity, } \\
\text { rat }\end{array}$ & $\begin{array}{l}\text { LED } \\
\text { Quantum } \\
\text { Devices } \\
\text { (Warp 10) }\end{array}$ & $670 \mathrm{~nm}$ & $\begin{array}{l}28 \mathrm{~mW} / \mathrm{cm}^{2} \\
4 \mathrm{~J} / \mathrm{cm}^{2}\end{array}$ & $\begin{array}{l}144 \mathrm{~s}, 5,25, \\
\text { and } 50 \mathrm{~h}-\text { post } \\
\text { Methanol }\end{array}$ & 2 days & $\begin{array}{l}\text { Photoreceptors } \\
\text { protected from } \\
\text { methanol toxicity } \\
\text { (ERG \& histology) }\end{array}$ \\
\hline $\begin{array}{l}\text { Kokkinopoulos et } \\
\text { al, } 2012 \text { Neurobiol } \\
\text { Aging [Epub ahead } \\
\text { of print] }\end{array}$ & NA & $\begin{array}{l}\text { Aging, } \\
\text { mice }\end{array}$ & $\begin{array}{l}\text { LED } \\
\text { Quantum } \\
\text { Devices } \\
\text { (Warp 10) }\end{array}$ & 670nm & $\begin{array}{l}40 \mathrm{~mW} / \mathrm{cm}^{2} \\
3.6 \mathrm{~J} / \mathrm{cm}^{2}\end{array}$ & $\begin{array}{l}5 \times 90 \mathrm{~s} \text {, every } \\
7 \text { hours }(35 \mathrm{hr} \\
\text { total treatment } \\
\text { time) }\end{array}$ & 7 days & $\begin{array}{l}\text { Shifted mitochond. } \\
\text { potential, reduced } \\
\text { inflammation in } \\
\text { outer retina. }\end{array}$ \\
\hline $\begin{array}{l}\text { Albarracin et al., } \\
\text { 2012 Jun } \\
1 ; 52(6): 3582-92 .\end{array}$ & NA & $\begin{array}{l}\text { Retinal light } \\
\text { damage } \\
(1000 \operatorname{lux}) \\
\text { rat }\end{array}$ & $\begin{array}{l}\text { LED } \\
\text { Quantum } \\
\text { Devices } \\
\text { (Warp 75) }\end{array}$ & $670 \mathrm{~nm}$ & $\begin{array}{l}60 \mathrm{~mW} / \mathrm{cm}^{2} \\
9 \mathrm{~J} / \mathrm{cm}^{2}\end{array}$ & $\begin{array}{l}176 \mathrm{~s} / \text { day for } 5 \\
\text { days, delivered } \\
\text { pre- or post- } \\
\text { light damage }\end{array}$ & 13 days & $\begin{array}{l}\text { Increased } \\
\text { protection and } \\
\text { survival of cone } \\
\text { photoreceptors }\end{array}$ \\
\hline $\begin{array}{l}\text { Albarracin et al, } \\
\text { Invest Ophthalmol } \\
\text { Vis Sci. 2011 Jun } \\
\text { 1;52(6):3582-92. }\end{array}$ & NA & $\begin{array}{l}\text { Retinal light } \\
\text { damage } \\
(1000 \text { lux }), \\
\text { rat }\end{array}$ & $\begin{array}{l}\text { LED } \\
\text { Quantum } \\
\text { Devices } \\
\text { (Warp 75) } \\
\end{array}$ & $670 \mathrm{~nm}$ & $\begin{array}{l}60 \mathrm{~mW} / \mathrm{cm}^{2} \\
9 \mathrm{~J} / \mathrm{cm}^{2}\end{array}$ & $\begin{array}{l}176 \mathrm{~s} / \text { day for } 5 \\
\text { days, delivered } \\
\text { pre-light } \\
\text { damage }\end{array}$ & 36 days & $\begin{array}{l}\text { Increased long- } \\
\text { term stability of the } \\
\text { retina following } \\
\text { acute light damage. }\end{array}$ \\
\hline $\begin{array}{l}\text { Qu et al., 2012: } \\
\text { 664:365-74 }\end{array}$ & NA & $\begin{array}{l}\text { Retinal light } \\
\text { damage } \\
(900,1800, \\
2700 \text { lux }), \\
\text { rat }\end{array}$ & $\begin{array}{l}\text { LED } \\
\text { Quantum } \\
\text { Devices } \\
\text { (Warp 10) }\end{array}$ & $670 \mathrm{~nm}$ & $\begin{array}{l}50 \mathrm{~mW} / \mathrm{cm}^{2} \\
90 \mathrm{~J} / \mathrm{cm}^{2}\end{array}$ & $\begin{array}{l}1800 \mathrm{~s}, 3 \text { hours } \\
\text { before and } 0,24 \\
\text { and } 48 \text { hours } \\
\text { post- light } \\
\text { damage }\end{array}$ & 2 days & $\begin{array}{l}\text { Protective effect on } \\
\text { retinal cells }\end{array}$ \\
\hline $\begin{array}{l}\text { Natoli et al., Mol } \\
\text { Vis. } 2010 \text { Sep } \\
3 ; 16: 1801-22 .\end{array}$ & NA & $\begin{array}{l}\text { Retinal light } \\
\text { damage } \\
(1000 \operatorname{lux}), \\
\text { rat }\end{array}$ & $\begin{array}{l}\text { LED } \\
\text { Quantum } \\
\text { Devices } \\
\text { (Warp 75) }\end{array}$ & $670 \mathrm{~nm}$ & $\begin{array}{l}60 \mathrm{~mW} / \mathrm{cm}^{2} \\
9 \mathrm{~J} / \mathrm{cm}^{2}\end{array}$ & $\begin{array}{l}176 \mathrm{~s} / \text { day for } 5 \\
\text { days, delivered } \\
\text { pre-light } \\
\text { damage }\end{array}$ & 6 days & $\begin{array}{l}\text { Photoreceptor } \\
\text { protection, } \\
\text { modulation retinal } \\
\text { gene expression. }\end{array}$ \\
\hline
\end{tabular}




\begin{tabular}{|c|c|c|c|c|c|c|c|c|}
\hline $\begin{array}{l}\text { Peoples et al, } 2012 \\
\text { ISRN Neurol. } \\
\text { [Epub ahead of } \\
\text { print] }\end{array}$ & NA & $\begin{array}{l}\text { Parkinson's } \\
\text { (MPTP- } \\
100 \mathrm{mg} / \mathrm{kg}), \\
\text { mice }\end{array}$ & $\begin{array}{l}\text { LED } \\
\text { Quantum } \\
\text { Devices } \\
\text { (Warp 10) }\end{array}$ & $670 \mathrm{~nm}$ & $\begin{array}{l}5 \mathrm{~mW} / \mathrm{cm}^{2} \\
0.5 \mathrm{~J} / \mathrm{cm} 2\end{array}$ & $\begin{array}{l}90 \mathrm{~s} \text {, Delivered } \\
\text { T0 and post- } \\
\text { insult }\end{array}$ & 56 days & $\begin{array}{l}\text { Protection of retina } \\
\text { from parkinsonian } \\
\text { insult }\end{array}$ \\
\hline $\begin{array}{l}\text { Albarracin R et al, } \\
\text { Photochem } \\
\text { Photobiol. } 2012 \\
\text { Feb 28.(Epub) }\end{array}$ & NA & $\begin{array}{l}\text { Retinal light } \\
\text { damage } \\
(1000 \text { lux }) \text {, } \\
\text { rat }\end{array}$ & \begin{tabular}{|l} 
LED \\
Quantum \\
Devices \\
(Warp 75) \\
\end{tabular} & $670 \mathrm{~nm}$ & $\begin{array}{l}60 \mathrm{~mW} / \mathrm{cm}^{2} \\
9 \mathrm{~J} / \mathrm{cm}^{2}\end{array}$ & $176 \mathrm{~s}$ & 13 days & $\begin{array}{l}\text { Increased } \\
\text { neuroprotection in } \\
\text { retina, possibly via } \\
\text { Müller cells }\end{array}$ \\
\hline $\begin{array}{l}\text { Rojas et al, J. } \\
\text { Neurosci, Dec 10, } \\
2008 \text { 28(50):13511 }\end{array}$ & NA & $\begin{array}{l}\text { Rotenone } \\
\text { inhibition, } \\
\text { rat }\end{array}$ & LEDtronics & $633 \mathrm{~nm}$ & $\begin{array}{l}2 \mathrm{~mW} / \mathrm{cm}^{2} \\
3.6 \mathrm{~J} / \mathrm{cm}^{2}\end{array}$ & $1800 \mathrm{~s}$ & 16 days & $\begin{array}{l}\text { Neuroprotection } \\
\text { against rotenone } \\
\text { toxicity }\end{array}$ \\
\hline \multicolumn{9}{|l|}{ Visual system } \\
\hline $\begin{array}{l}\text { Wong-Riley et al., } \\
\text { 2001. NeuroReport } \\
12 \text { p3033 }\end{array}$ & $\begin{array}{l}\text { Visual } \\
\text { cortex } \\
\text { neurons, } \\
\text { rat } \\
\end{array}$ & NA & $\begin{array}{l}\text { LED, } \\
\text { Quantum } \\
\text { Devices }\end{array}$ & $670 \mathrm{~nm}$ & $\begin{array}{l}50 \mathrm{~mW} / \mathrm{cm}^{2}, \\
4 \mathrm{~J} / \mathrm{cm}^{2}\end{array}$ & $80 \mathrm{~s} /$ day & 6 days & $\begin{array}{l}\text { Increased COX } \\
\text { activity }\end{array}$ \\
\hline $\begin{array}{l}\text { Wong-Riley et al., } \\
\text { 2005. J Biol } \\
\text { Chem,. 280(6): } \\
\text { p4761 }\end{array}$ & \begin{tabular}{|l} 
Visual \\
cortex \\
neurons, \\
rat
\end{tabular} & NA & $\begin{array}{l}\text { LED, } \\
\text { Quantum } \\
\text { Devices }\end{array}$ & $\begin{array}{l}670 \mathrm{~nm} \\
728 \mathrm{~nm} \\
770 \mathrm{~nm} \\
830 \mathrm{~nm} \\
880 \mathrm{~nm}\end{array}$ & $\begin{array}{l}50 \mathrm{~mW} / \mathrm{cm}^{2}, \\
4 \mathrm{~J} / \mathrm{cm}^{2}\end{array}$ & $\begin{array}{l}80 \text { s / day, once } \\
\text { or twice / day }\end{array}$ & 6 days & $\begin{array}{l}\text { 670, 830nm } \\
\text { increased ATP and } \\
\text { COX with COX } \\
\text { inhibitor KCN, but } \\
\text { not tetrodotoxin }\end{array}$ \\
\hline $\begin{array}{l}\text { Liang et al., } 2006 . \\
\text { Neuroscience. } \\
\text { 139(2): p639 }\end{array}$ & $\begin{array}{l}\text { Visual } \\
\text { cortex } \\
\text { neurons, } \\
\text { rat }\end{array}$ & NA & $\begin{array}{l}\text { LED, } \\
\text { Quantum } \\
\text { Devices }\end{array}$ & $670 \mathrm{~nm}$ & $\begin{array}{l}50 \mathrm{~mW} / \mathrm{cm}^{2}, \\
30 \mathrm{~J} / \mathrm{cm}^{2}\end{array}$ & $10 \mathrm{~min}$ & $28 \mathrm{hrs}$ & $\begin{array}{l}\text { Decreased ROS } \\
\text { and apoptosis } \\
\text { induced by } \mathrm{KCN}\end{array}$ \\
\hline $\begin{array}{l}\text { Fitzgerald et al., } \\
\text { 2010. J } \\
\text { Neurotrauma, } \\
\text { 27(11): p2107 }\end{array}$ & NA & $\begin{array}{l}\text { Partial ON } \\
\text { injury, rat }\end{array}$ & $\begin{array}{l}\text { LED, } \\
\text { Quantum } \\
\text { Devices } \\
\text { (Warp 10) }\end{array}$ & $670 \mathrm{~nm}$ & $\begin{array}{l}25 \mathrm{~mW} / \mathrm{cm}^{2}, \\
\ldots\end{array}$ & $30 \mathrm{~min} / \mathrm{day}$ & $\begin{array}{l}8-10 \\
\text { days }\end{array}$ & $\begin{array}{l}\text { Reduced ox stress, } \\
\text { limited OPC } \\
\text { increases, restored } \\
\text { visual function }\end{array}$ \\
\hline $\begin{array}{l}\text { Assia et al., } 1989 . \\
\text { Brain Res, 476(2): } \\
\text { p205 }\end{array}$ & NA & ON crush, rat & He-Ne laser & $630 \mathrm{~nm}$ & $10.5 \mathrm{~mW}$ & $\begin{array}{l}2 \min / \text { day, for } \\
4,7 \text { or } 14 \text { days }\end{array}$ & $\begin{array}{l}14 \text { or } \\
21 \text { days }\end{array}$ & $\begin{array}{l}\text { Increased CAP; if } \\
\text { moderate injury, } \\
\text { early and continued }\end{array}$ \\
\hline
\end{tabular}




\begin{tabular}{|c|c|c|c|c|c|c|c|c|}
\hline \multicolumn{9}{|l|}{$S C I$} \\
\hline $\begin{array}{l}\text { Byrnes et al., } \\
\text { 2005. Lasers Surg } \\
\text { Med 36: p171 }\end{array}$ & NA & $\begin{array}{l}\text { SCI } \\
\text { dorsal hemi- } \\
\text { section T9, } \\
\text { rat }\end{array}$ & $\begin{array}{l}\text { Laser, } \\
\text { Thor } \\
\text { International }\end{array}$ & $810 \mathrm{~nm}$ & $\begin{array}{l}150 \mathrm{~mW}, \\
1,589 \mathrm{~J} / \mathrm{cm}^{2} / \\
\text { day (at skin) }\end{array}$ & $\begin{array}{l}50 \text { min / day for } \\
14 \text { days } \\
\text { (starting } 15 \text { min } \\
\text { after surgery). }\end{array}$ & 9wks & $\begin{array}{l}\text { Improved axonal } \\
\text { number, regrowth, } \\
\text { and some function. } \\
\text { Immunomodulation }\end{array}$ \\
\hline $\begin{array}{l}\text { Wu et al., } 2009 . \\
\text { Lasers Surg Med. } \\
\text { 41: p36 }\end{array}$ & NA & $\begin{array}{l}\text { SCI } \\
\text { contusionT10 } \\
\text { dorsal hemi- } \\
\text { section T9, } \\
\text { rat }\end{array}$ & $\begin{array}{l}\text { Laser, } \\
\text { Thor } \\
\text { International }\end{array}$ & $810 \mathrm{~nm}$ & $\begin{array}{l}150 \mathrm{~mW} \\
1,589 \mathrm{~J} / \mathrm{cm}^{2} / \\
\text { day (at skin) }\end{array}$ & $\begin{array}{l}50 \mathrm{~min} / \text { day for } \\
14 \text { days } \\
\text { (starting } \\
\text { immediately } \\
\text { after surgery). }\end{array}$ & $3 w k s$ & $\begin{array}{l}\text { Increased axon } \\
\text { length and number, } \\
\text { and open field } \\
\text { (BBB) locomotion } \\
\text { in contusion model } \\
\end{array}$ \\
\hline $\begin{array}{l}\text { Medalha et al } \\
\text { 2010. Photomed } \\
\text { Laser Surg 28: } \\
\text { p669 }\end{array}$ & NA & $\begin{array}{l}\text { SCI } \\
\text { Complete } \\
\text { transection } \\
\text { T9-10, rat }\end{array}$ & $\begin{array}{l}\text { Laser, } \\
\text { Teralaser } \\
\text { (MM Optics } \\
\text { Ltd) } \\
\end{array}$ & 830nm, & $\begin{array}{l}30 \mathrm{~mW} / \mathrm{cm}, \\
250 \mathrm{~J} / \mathrm{cm}^{2} \\
(\mathrm{CW})\end{array}$ & $\begin{array}{l}70 \text { s/day } 3 \mathrm{x} / \mathrm{wk} \\
\text { at } 2 \text { points on } \\
\text { hindlimb, (not } \\
\text { on spinal cord) }\end{array}$ & 4wks & $\begin{array}{l}\text { No improvements. } \\
\text { Note: treatment not } \\
\text { applied directly to } \\
\text { spinal cord }\end{array}$ \\
\hline \multicolumn{9}{|l|}{$T B I$} \\
\hline $\begin{array}{l}\text { Oron } \text { et al., } 2007 \mathrm{~J} \\
\text { Neurotrauma } 24: \\
\text { p651 }\end{array}$ & NA & $\begin{array}{l}\text { TBI } \\
\text { acute cortical } \\
\text { impactor, } \\
94 \mathrm{~g}, \text { mice }\end{array}$ & $\begin{array}{l}\text { Laser, } \\
\text { Photothera } \\
\text { Inc. }\end{array}$ & $808 \mathrm{~nm}$ & $\begin{array}{l}10 \text { and } \\
20 \mathrm{~m} / \mathrm{W} / \mathrm{cm}^{2} \\
\left(1.2-2.4 \mathrm{~J} / \mathrm{cm}^{2}\right)\end{array}$ & $\begin{array}{l}2 \text { min (at } 4 \mathrm{hrs} \\
\text { post trauma) }\end{array}$ & 4 wks & $\begin{array}{l}\text { Improved } \\
\text { neurobehavioural } \\
\text { function (NSS) and } \\
\text { reduced lesion size }\end{array}$ \\
\hline $\begin{array}{l}\text { Moriera et al., } \\
\text { 2009. J Photochem } \\
\text { Photobiol B. 97: } \\
\text { p145 }\end{array}$ & NA & $\begin{array}{l}\text { TBI } \\
\text { focal } \\
\text { cryoinjury, } \\
\text { rat }\end{array}$ & $\begin{array}{l}\text { Laser } \\
\text { Teralaser } \\
\text { (MM Optics } \\
\text { Ltd) }\end{array}$ & $\begin{array}{l}660 \mathrm{~nm} \\
780 \mathrm{~nm}\end{array}$ & $\begin{array}{l}40 \mathrm{~mW} \\
3-5 \mathrm{~J} / \mathrm{cm}^{2} / \\
\text { point }(\mathrm{CW})\end{array}$ & $\begin{array}{l}\text { Immediately } \\
\text { and } 3 \text { hrs after } \\
\text { TBI }\end{array}$ & $24 \mathrm{hrs}$ & $\begin{array}{l}\text { Immunomodulation } \\
\text { of TNF- } \alpha, \text { IL10, } \\
\text { IL1 } \beta \text { cytokine } \\
\text { responses }\end{array}$ \\
\hline $\begin{array}{l}\text { McCarthy et al., } \\
\text { 2010. Photomed } \\
\text { Laser Surg 30: } \\
\text { p663 }\end{array}$ & NA & $\begin{array}{l}\text { Uninjured } \\
\text { brain, rat }\end{array}$ & $\begin{array}{l}\text { Laser } \\
\text { ND }\end{array}$ & $808 \mathrm{~nm}$ & $\begin{array}{l}2230 \mathrm{~mW} / \mathrm{cm}^{2} \\
268 \mathrm{~J} / \mathrm{cm}^{2} \text { or } \\
10 \mathrm{~mW} / \mathrm{cm}^{2} \\
1.2 \mathrm{~J} / \mathrm{cm}^{2}\end{array}$ & $\begin{array}{l}5 \text { min on day } 1, \\
\text { or on each of } \\
\text { days } 1,3,5\end{array}$ & 1 year & $\begin{array}{l}\text { Single and multiple } \\
\text { doses safe }\end{array}$ \\
\hline $\begin{array}{l}\text { Ando et al., } 2011 . \\
\text { PLoS One 6: } \\
\text { e26212 }\end{array}$ & NA & $\begin{array}{l}\text { TBI } \\
\text { acute, AMS } \\
201 \text { impactor, } \\
\text { mice }\end{array}$ & $\begin{array}{l}\text { Laser, } \\
\text { DioDent } \\
\text { Micro 810, } \\
\text { (HOYA) }\end{array}$ & $810 \mathrm{~nm}$ & $\begin{array}{l}50 \mathrm{~mW} / \mathrm{cm}^{2}, \\
36 \mathrm{~J} / \mathrm{cm}^{2}, \\
10-\mathrm{Hz} \mathrm{CW} ; \\
100-\mathrm{Hz} \mathrm{PW}\end{array}$ & $\begin{array}{l}12 \text { min at } 4 \mathrm{hrs} \\
\text { post TBI }\end{array}$ & 4wks & \begin{tabular}{|l|} 
Improved NSS, \\
reduced lesion \\
volume, anti- \\
depressant. $10-\mathrm{Hz}$ \\
PW better effect
\end{tabular} \\
\hline
\end{tabular}




\begin{tabular}{|c|c|c|c|c|c|c|c|c|}
\hline $\begin{array}{l}\text { Naeser } \text { et al., } 2011 . \\
\text { Photomed Laser } \\
\text { Surg 29: p351 }\end{array}$ & NA & $\begin{array}{l}\text { Chronic TBI, } \\
\text { Human } \\
\text { (Females, } \\
\text { 59yrs, 52yrs) }\end{array}$ & $\begin{array}{l}\text { Laser, } 2 \\
\text { devices, ND }\end{array}$ & $\begin{array}{l}633 \mathrm{~nm}, \\
870 \mathrm{~nm} \\
(\mathrm{CW})\end{array}$ & $\begin{array}{l}25.8 \mathrm{~mW} / \mathrm{cm}^{2} \\
\text { or } \\
22.2 \mathrm{~mW} / \mathrm{cm}^{2}\end{array}$ & $\begin{array}{l}310-774 \mathrm{~s} / \mathrm{wk} \\
7 \text { mths, then } 3 \\
\text { wks/month or } \\
7-10 \mathrm{~min} / \text { day }\end{array}$ & $\begin{array}{l}7 \mathrm{yrs} \\
\text { 4month }\end{array}$ & $\begin{array}{l}\text { Improved } \\
\text { executive function, } \\
\text { reduced post } \\
\text { traumatic stress. }\end{array}$ \\
\hline $\begin{array}{l}\text { Nawashiro et al., } \\
\text { 2012. Photomed } \\
\text { Laser Surg 30: } \\
\text { p231 }\end{array}$ & NA & $\begin{array}{l}\text { TBI, Human } \\
\text { (Male 40yrs) }\end{array}$ & $\begin{array}{l}\text { Laser, Sun- } \\
\text { Mechatronics }\end{array}$ & $\begin{array}{l}830- \\
870 \mathrm{~nm}\end{array}$ & $\begin{array}{l}299 \mathrm{~mW} \\
11.4 \mathrm{~mW} / \mathrm{cm}^{2}, \\
20.5 \mathrm{~J} / \mathrm{cm}^{2}\end{array}$ & $\begin{array}{l}2 \times 30 \mathrm{~min} / \text { day, } \\
\text { applied } 5 \mathrm{~mm} \\
\text { from skin. }\end{array}$ & 73days & $\begin{array}{l}\text { Some neurological } \\
\text { improvement, } \\
\text { increased cerebral } \\
\text { blood flow }\end{array}$ \\
\hline $\begin{array}{l}\text { Khuman et al., } \\
\text { 2012. J } \\
\text { Neurotrauma. 29: } \\
\text { p408 }\end{array}$ & NA & $\begin{array}{l}\text { TBI } \\
\text { cortical } \\
\text { piston, } 3 \mathrm{~mm} \\
\text { wide, } 6 \mathrm{~m} / \mathrm{sec} \text {, } \\
100 \mathrm{msec} \text {, } \\
\text { depth } 0.6 \mathrm{~mm} \text {, } \\
\text { mice }\end{array}$ & $\begin{array}{l}\text { Laser, } \\
\text { Thor } \\
\text { International }\end{array}$ & $800 \mathrm{~nm}$ & $\begin{array}{l}\text { Craniotomy: } \\
250-500 \\
\mathrm{~mW} / \mathrm{cm}^{2} \\
30-210 \mathrm{~J} / \mathrm{cm}^{2} \\
\text { Transcranial: } \\
500 \mathrm{~mW} / \mathrm{cm}^{2}\end{array}$ & $\begin{array}{l}\text { Craniotomy: } \\
\text { 2-7min, 60- } \\
\text { 80min post TBI } \\
\text { Transcranial: } \\
2 \text { min, 60- } \\
80 \mathrm{~min} \text { or } 4 \mathrm{hrs} \\
\text { post TBI }\end{array}$ & $1 w k$ & $\begin{array}{l}\text { Improved cognition } \\
\text { inhibition of } \\
\text { microglia. No } \\
\text { effect on motor } \\
\text { function, edema, } \\
\text { nitrosative stress, } \\
\text { or lesion volume }\end{array}$ \\
\hline $\begin{array}{l}\text { Wu et al., } 2012 . \\
\text { Lasers Surg Med } \\
\text { 44: p218 }\end{array}$ & NA & $\begin{array}{l}\text { TBI, } \\
\text { acute } \\
\text { Impactor, } \\
\text { mice }\end{array}$ & $\begin{array}{l}\text { Laser, } \\
\text { Diomed Inc, } \\
\text { or V-Raser, } \\
\text { (Con-Bio) } \\
\end{array}$ & $\begin{array}{l}665 \mathrm{~nm} \\
730 \mathrm{~nm} \\
810 \mathrm{~nm} \\
980 \mathrm{~nm} \\
\end{array}$ & $\begin{array}{l}36 \mathrm{~J} / \mathrm{cm} 2 \\
(\mathrm{CW})\end{array}$ & $\begin{array}{l}1 \mathrm{x} 4-\mathrm{min} \text {, at } 4 \mathrm{hr} \\
\text { post-injury }\end{array}$ & 4wks & $\begin{array}{l}\text { Improved NSS, } \\
\text { reduced brain } \\
\text { "deficits" with } \\
665 \mathrm{~nm} \text { and } 810 \mathrm{~nm}\end{array}$ \\
\hline $\begin{array}{l}\text { Quirk et al., } 2012 . \\
\text { Photomed Laser } \\
\text { Surg 30: p1 }\end{array}$ & NA & $\begin{array}{l}\text { TBI, } \\
\text { cortical } \\
\text { impactor, } \\
6 \mathrm{~mm} / \mathrm{sec}, \\
3 \mathrm{~mm} \text {, rat }\end{array}$ & $\begin{array}{l}\text { LED, } \\
\text { Quantum } \\
\text { Devices }\end{array}$ & $670 \mathrm{~nm}$ & $\begin{array}{l}50 \mathrm{~mW} / \mathrm{cm}^{2}, \\
15 \mathrm{~J} / \mathrm{cm}^{2}\end{array}$ & $\begin{array}{l}2 \times 5 \mathrm{~min} / \text { day } \\
\text { for } 72 \mathrm{hrs} \text { or } 10 \\
\text { days (top of } \\
\text { head, } 0.5 \mathrm{~cm} \\
\text { from scalp) }\end{array}$ & 10 days & $\begin{array}{l}\text { Improved NSS, } \\
\text { decreased Bax, } \\
\text { increased Bcl2 }\end{array}$ \\
\hline $\begin{array}{l}\text { Oron } \text { et al., } 2012 \mathrm{~J} \\
\text { Neurotrauma 29: } \\
\text { p401 }\end{array}$ & NA & $\begin{array}{l}\text { TBI } \\
\text { cortical } \\
\text { impactor, 94g } \\
\text { mice }\end{array}$ & $\begin{array}{l}\text { Laser, } \\
\text { Photothera } \\
\text { Inc., }\end{array}$ & $808 \mathrm{~nm}$ & $\begin{array}{l}10 \mathrm{~m} / \mathrm{W} / \mathrm{cm}^{2} \\
1.2 \mathrm{~J} / \mathrm{cm}^{2}\end{array}$ & $\begin{array}{l}2 \min (4,6, \text { or } 8 \\
\text { hrs post- } \\
\text { trauma), } \mathrm{PW} \\
100 \text { or } 600 \mathrm{~Hz}\end{array}$ & 56 days & $\begin{array}{l}\text { Improved NSS } \\
\text { reduced lesion size }\end{array}$ \\
\hline \multicolumn{9}{|l|}{ Stroke } \\
\hline $\begin{array}{l}\text { Lapchak et al., } \\
\text { 2004. Stroke } 35 \\
\text { p1985-1988 }\end{array}$ & & $\begin{array}{l}\text { RSCEM, } \\
\text { rabbit }\end{array}$ & $\begin{array}{l}\text { Acculaser } \\
\text { PhotoThera } \\
\text { Inc. }\end{array}$ & $808 \mathrm{~nm}$ & $\begin{array}{l}25 \mathrm{~mW} / \mathrm{cm}^{2} \text { or } \\
7.5 \mathrm{~mW} / \mathrm{cm}^{2} \\
(\mathrm{CW})\end{array}$ & $\begin{array}{l}2 \text { or } 10 \mathrm{mins} \\
\text { at } 1 \text { or } 24 \mathrm{hrs} \\
\text { post insult }\end{array}$ & $\begin{array}{l}\text { Up to } \\
21 \text { days }\end{array}$ & $\begin{array}{l}\text { Improved } \\
\text { behavioural } \\
\text { performance }\end{array}$ \\
\hline
\end{tabular}




\begin{tabular}{|c|c|c|c|c|c|c|c|c|}
\hline $\begin{array}{l}\text { DeToboada } \text { et al., } \\
\text { 2006. Las. Surg. } \\
\text { Med. } 38 \text { p } 70-73\end{array}$ & & MCAO, rats & $\begin{array}{l}\text { Ga-Al-As } \\
\text { diode laser, } \\
\text { PhotoThera } \\
\end{array}$ & $808 \mathrm{~nm}$ & $7.5 \mathrm{~mW} / \mathrm{cm}^{2}$ & $2 \mathrm{~min}$ & $\begin{array}{l}\text { Up to } \\
28 \text { days }\end{array}$ & \begin{tabular}{|l|} 
Reduced \\
neurological \\
deficits \\
\end{tabular} \\
\hline $\begin{array}{l}\text { Oron et al., } 2006 . \\
\text { Stroke } 37 \text { p2620- } \\
2624\end{array}$ & & MCAO, rats & $\begin{array}{l}\text { Ga-Al-As } \\
\text { diode laser, } \\
\text { PhotoThera } \\
\text { Inc }\end{array}$ & $808 \mathrm{~nm}$ & $\begin{array}{l}7.5 \mathrm{~mW} / \mathrm{cm}^{2} \\
(\mathrm{CW} \text { and/or } \\
\mathrm{PW})\end{array}$ & $\begin{array}{l}2 \text { min at } 4 \text { or } 24 \\
\text { hrs post-stroke }\end{array}$ & $\begin{array}{l}\text { Up to } \\
21 \text { days }\end{array}$ & \begin{tabular}{|l|} 
Improved \\
neurological \\
outcome with $24 \mathrm{hr}$. \\
No improvement in \\
stroke volume
\end{tabular} \\
\hline $\begin{array}{l}\text { Lapchak et al., } \\
2007 \text { Neuroscience } \\
148 \text { p } 907-914\end{array}$ & & $\begin{array}{l}\text { RSCEM, } \\
\text { rabbits }\end{array}$ & $\begin{array}{l}\text { Acculaser, } \\
\text { PhotoThera } \\
\text { Inc. }\end{array}$ & $808 \mathrm{~nm}$ & $\begin{array}{l}7.5 \mathrm{~mW} / \mathrm{cm}^{2} \\
(\mathrm{CW} \text { or } \mathrm{PW})\end{array}$ & $\begin{array}{l}2 \text { min at } 6 \text { or } 12 \\
\text { hrs post- } \\
\text { embolisation }\end{array}$ & $48 \mathrm{hrs}$ & $\begin{array}{l}\text { Significant } \\
\text { improvement with } \\
\text { PW at } 6 \text { hrs }\end{array}$ \\
\hline $\begin{array}{l}\text { Lapchak et al., } \\
\text { 2008. Stroke. } 39 \\
\text { p307303078 }\end{array}$ & & $\begin{array}{l}\text { RSCEM, } \\
\text { rabbit }\end{array}$ & $\begin{array}{l}\text { Acculaser, } \\
\text { PhotoThera } \\
\text { Inc. }\end{array}$ & $808 \mathrm{~nm}$ & $10 \mathrm{~mW} / \mathrm{cm}^{2}$ & $\begin{array}{l}2 \text { min at } 90 \mathrm{~min} \\
\text { post- } \\
\text { embolisation }\end{array}$ & $24 \mathrm{hrs}$ & $\begin{array}{l}\text { Safe with tPA, } \\
\text { haemorrhage and } \\
\text { volume unaffected. }\end{array}$ \\
\hline $\begin{array}{l}\text { Lapchak \& } \\
\text { DeTaboada } 2010 . \\
\text { Brain Res. } 1306 \\
\text { p100-105 }\end{array}$ & & $\begin{array}{l}\text { RSCEM, } \\
\text { rabbit }\end{array}$ & $\begin{array}{l}\text { Ga-Al-As } \\
\text { diode laser, } \\
\text { PhotoThera } \\
\text { Inc }\end{array}$ & $808 \mathrm{~nm}$ & $\begin{array}{l}7.5 \mathrm{~mW} / \mathrm{cm}^{2} \\
(\mathrm{CW}) \\
37.5 \mathrm{~mW} / \mathrm{cm}^{2} \\
(\mathrm{PW} 1,100 \mathrm{~Hz}) \\
262.2 \mathrm{~mW} / \mathrm{cm}^{2} \\
(\mathrm{PW} 2,100 \mathrm{~Hz})\end{array}$ & $\begin{array}{l}5 \mathrm{~min} \text { post- } \\
\text { embolization } \\
\mathrm{CW}-2 \mathrm{~min} \\
\mathrm{PW} 1-2 \mathrm{~min} \text {, } \\
3.5 \mathrm{~mJ} / \mathrm{pulse} \text {, } \\
\mathrm{PW} 2-2 \mathrm{~min} \\
24.5 \mathrm{~mJ} / \text { pulse, }\end{array}$ & $3 \mathrm{hrs}$ & $\begin{array}{l}\text { Increased cortical } \\
\text { ATP content. }\end{array}$ \\
\hline \multicolumn{9}{|l|}{$P D$} \\
\hline $\begin{array}{l}\text { Ying et al., } 2008 . \\
\text { Brain Res. } 1243 \text { p } \\
167-173\end{array}$ & $\begin{array}{l}\text { Cortical } \\
\text { neurons; } \\
\text { rotenone } \\
\& \text { MPTP } \\
\text { rat }\end{array}$ & NA & $\begin{array}{l}\text { LED, } \\
\text { Quantum } \\
\text { Devices }\end{array}$ & $670 \mathrm{~nm}$ & $\begin{array}{l}50 \mathrm{~mW} / \mathrm{cm}^{2} ; \\
4 \mathrm{~J} / \mathrm{cm}^{2}\end{array}$ & 80 s twice / day & $\begin{array}{l}2-4 \\
\text { days }\end{array}$ & $\begin{array}{l}\text { Reduced apoptosis } \\
\text { and increased ATP } \\
\text { content }\end{array}$ \\
\hline $\begin{array}{l}\text { Liang et al., } 2008 . \\
\text { Neuroscience } 153 \\
\text { p 963-974 }\end{array}$ & $\begin{array}{l}\text { neurons; } \\
\text { rotenone } \\
\& \text { MPTP } \\
\text { rat }\end{array}$ & NA & $\begin{array}{l}\text { LED, } \\
\text { Quantum } \\
\text { Devices }\end{array}$ & $670 \mathrm{~nm}$ & $\begin{array}{l}50 \mathrm{~mW} / \mathrm{cm}^{2} ; \\
4 \mathrm{~J} / \mathrm{cm}^{2}\end{array}$ & 80 s twice / day & $\begin{array}{l}3-5 \\
\text { days }\end{array}$ & $\begin{array}{l}\text { Increased ATP } \\
\text { content, decreased } \\
\text { neuronal apoptosis, } \\
\text { reduced ROS and } \\
\text { NO }\end{array}$ \\
\hline
\end{tabular}




\begin{tabular}{|c|c|c|c|c|c|c|c|c|}
\hline $\begin{array}{l}\text { Shaw et al., } 2010 . \\
\text { J Comp Neurol } \\
518 \text { p } 25-40\end{array}$ & NA & $\begin{array}{l}\text { acute PD, 50- } \\
100 \mathrm{mg} / \mathrm{kg} \text { ip } \\
\text { MPTP over } \\
30 \mathrm{~h} ; \text { mice }\end{array}$ & $\begin{array}{l}\text { LED, } \\
\text { Quantum } \\
\text { Devices }\end{array}$ & $670 \mathrm{~nm}$ & $\begin{array}{l}40 \mathrm{~mW} / \mathrm{cm}^{2} \\
5.3 \mathrm{~J} / \mathrm{cm}^{2}\end{array}$ & $\begin{array}{l}90 \mathrm{~s} ; 4 \text { times } \\
\text { over } 30 \mathrm{~h}\end{array}$ & $30 \mathrm{~h}$ & $\begin{array}{l}\text { Increased number } \\
\text { of surviving } \\
\text { dopaminergic cells } \\
\text { in substantia nigra }\end{array}$ \\
\hline $\begin{array}{l}\text { Peoples et al., } \\
\text { 2012. Parkinson } \\
\text { Related Dis p 469- } \\
476 .\end{array}$ & NA & $\begin{array}{l}\text { acute and } \\
\text { chronic PD; } \\
10 \times 20 \mathrm{mg} / \mathrm{kg} \\
\text { ip over } 5 \\
\text { wks; mice }\end{array}$ & $\begin{array}{l}\text { LED, } \\
\text { Quantum } \\
\text { Devices }\end{array}$ & $670 \mathrm{~nm}$ & $\begin{array}{l}40 \mathrm{~mW} / \mathrm{cm}^{2} \\
5 \mathrm{~J} / \mathrm{cm}^{2}\end{array}$ & $90 \mathrm{~s} ; 10$ times & $\begin{array}{l}3-8 \\
\text { weeks }\end{array}$ & $\begin{array}{l}\text { Increased number } \\
\text { of surviving } \\
\text { dopaminergic cells } \\
\text { in substantia nigra }\end{array}$ \\
\hline \multicolumn{9}{|l|}{ Other } \\
\hline $\begin{array}{l}\text { Yan et al., 2011. J } \\
\text { Peripheral Nervous } \\
\text { System 16: p130 }\end{array}$ & NA & $\begin{array}{l}\text { Pain, } \\
\text { rat }\end{array}$ & Irradia $^{\mathrm{TM}}$ & $\begin{array}{l}650 \mathrm{~nm} \\
808 \mathrm{~nm}\end{array}$ & $\begin{array}{l}35 \mathrm{~mW} \\
450 \mathrm{~mW}\end{array}$ & $\begin{array}{l}\text { 30s to each of } 4 \\
\text { points }\end{array}$ & & $\begin{array}{l}\text { Decreased SSEP } \\
\text { and CMAP } \\
\text { amplitudes } \\
\text { indicated potential } \\
\text { pain relief }\end{array}$ \\
\hline
\end{tabular}

NA is not appropriate, ND is not described, abbreviations for laser type are combinations of the following elements: gallium (Ga), aluminium (AI) or arsenide (As). Abbreviations: Basso, Beattie and Bresnahan (BBB), cytochrome c oxidase (COX), continuous wave (CW), pulsed Wave (PW), Neurological Severity Score (NSS); spinal cord injury (SCI); optic nerve (ON), traumatic brain injury(TBI), oligodendrocyte precursor cells (OPCs), compound action potentials (CAP), seconds (s), minutes (min), hours (hrs), weeks (wks), small clot embolic stroke model (RSCEM), middle cerebral artery occlusion (MCAO), somatosensory evoked potential (SSEP), comprehensive muscular activity profile (CMAP). 
Table 2. Currently registered trials on the WHO International Clinical Trials Registry Platform Search Portal.

\begin{tabular}{|l|l|l|}
\hline Title & $\begin{array}{l}\text { Registration } \\
\text { date }\end{array}$ & Status \\
\hline $\begin{array}{l}\text { Brain plasticity underlying back pain response to different } \\
\text { acupuncture methods }\end{array}$ & $5 / 2012$ & $\mathrm{NR}$ \\
\hline Effects of LEDs on memory in TBI patients & $5 / 2012$ & $\mathrm{R}$ \\
\hline $\begin{array}{l}\text { Transcranial laser therapy in the rehabilitation of hemiplegic } \\
\text { patients from ischaemic stroke }\end{array}$ & $3 / 2011$ & $\mathrm{NR}$ \\
\hline $\begin{array}{l}\text { Safety of Rt-PA + transcranial emission of low energy lasers for } \\
\text { acute stroke recovery }\end{array}$ & $10 / 2010$ & $\mathrm{R}$ \\
\hline $\begin{array}{l}\text { Efficacy and safety trial of transcranial laser therapy within } \\
\text { 24hours from stroke onset (NEST-3) }\end{array}$ & $5 / 2010$ & $\mathrm{R}$ \\
\hline Brain effects of acupuncture 2: Laser acupuncture vs laser EMLA & $4 / 2010$ & $\mathrm{NR}$ \\
\hline $\begin{array}{l}\text { Brain effects of acupuncture 2: Needle acupuncture vs laser } \\
\text { acupuncture }\end{array}$ & $4 / 2010$ & $\mathrm{NR}$ \\
\hline $\begin{array}{l}\text { Managing fatigue and sleep disturbance following traumatic brain } \\
\text { injury }\end{array}$ & $7 / 2008$ & $\mathrm{R}$ \\
\hline $\begin{array}{l}\text { Managing fatigue and sleep disturbance following traumatic brain } \\
\text { injury }\end{array}$ & $1 / 2008$ & $\mathrm{NR}$ \\
\hline $\begin{array}{l}\text { Effectiveness and safety trial of a new ischaemic stroke treatment } \\
\text { within 24 hours from stroke onset (NEST-2) }\end{array}$ & $1 / 2007$ & $\mathrm{NR}$ \\
\hline
\end{tabular}

$\mathrm{R}=$ recruiting; $\mathrm{NR}=$ Not recruiting 